\title{
Biofortification of major crop plants with iron and zinc - achievements and future directions
}

\author{
James C. R. Stangoulis $®$ Marija Knez
}

Received: 6 August 2021 / Accepted: 6 February 2022 / Published online: 17 February 2022

(C) The Author(s) 2022

\begin{abstract}
Biofortification is a long-term strategy of delivering more iron $(\mathrm{Fe})$ and zinc $(\mathrm{Zn})$ to those most in need. Plant breeding programs within the CGIAR and NARS have made major advances in Fe- and Zndense variety development and there have been successful releases of new biofortified varieties. Recent research effort has led to a substantial improvement in our knowledge of $\mathrm{Fe}$ and $\mathrm{Zn}$ homeostasis and gene regulation, resulting in the identification of candidate genes for marker assisted selection. International cooperation between the agricultural and nutrition community has been strengthened, with numerous implementation and partnership strategies developed and employed over the years. The evidence on the effectiveness of $\mathrm{Fe}$ and $\mathrm{Zn}$ biofortified crops is slowly building up and the results are encouraging. Biofortification continues to be scaled out and further work is required to reach the general aim of eradicating the hidden hunger of Fe and Zn deficiency in the world's population and ensuring nutritional security.
\end{abstract}

Responsible Editor: Ismail Cakmak.

J. C. R. Stangoulis $(\square)$

College of Science and Engineering, Flinders University, GPO Box 2100, Adelaide, SA 5001, Australia

e-mail: james.stangoulis@ flinders.edu.au

\section{Knez}

Center of Research Excellence in Nutrition and Metabolism, Institute for Medical Research, National Institute of the Republic of Serbia, University of Belgrade, Belgrade 11000, Serbia
Keywords Biofortification - Zinc $\cdot$ Iron $\cdot$ Crop plants $\cdot$ Biofortification strategies $\cdot$ Micronutrient deficiencies $\cdot$ Nutrition $\cdot$ Plant breeding $\cdot$ Low-income countries

\section{Introduction}

The global population is expected to increase from 7.6 billion in 2017 to 8.6 billion in 2030 and 9.8 billion by 2050 (United Nations 2016). Currently, $40 \%$ of pregnant women and $42 \%$ of children below 5 years of age are anaemic and $17 \%$ of the global population is at risk of inadequate $\mathrm{Zn}$ intakes (WHO 2021). The task of feeding this growing population with both sufficient food and $\mathrm{Fe}$ and $\mathrm{Zn}$, is of critical importance.

Dietary diversity is the optimal route for delivering adequate nutrition but diets of low-income, poor families in developing countries predominantly involve staple based, plant products and many of these foods (such as cereals) are low in nutrients (Bouis and Welch 2010).

With the advent of the Green Revolution, higheryielding cereal crops were developed and while this was critical for providing more staple food to undernourished populations, it also led to a reliance on low micronutrient staples in the diet (Welch and Graham 2004). A historical example of the effects of selecting on high yield and not considering micronutrients, can be visualised with wheat. Over 
a 120-year period of taking records, hard white wheat varieties were shown to have an increase in yield of up to $175 \%$ but this coincided with a decrease of 11 to $25 \%$ in $\mathrm{Fe}$ and $\mathrm{Zn}$ concentration, respectively (Murphy et al. 2008). The cause for this is not entirely understood but it is thought to be due to a possible "dilution effect" caused by the increase in grain size and a change in the ratio of bran to endosperm in modern varieties (Murphy et al. 2008). Biofortification aimed to rectify this imbalance by not only breeding for improved agronomic performance, but also redirecting efforts to improve the $\mathrm{Fe}$ and $\mathrm{Zn}$ concentration of new varieties being developed.

A question often posed is whether we can have both high yield and high micronutrient concentration? In the case of wheat, despite the historically inverse relationship between yield and micronutrient concentrations, it has been shown that these traits are controlled by separate genetic pathways (Velu et al. 2018a), consequently it is feasible to breed for both high yield and high nutrient genotypes, thereby negating the dilution effect due to high yield. Furthermore, (Velu et al. 2018a) have shown that QTL for larger seed size and $\mathrm{Zn}$ concentration are co-located, thereby enabling the simultaneous increase of yield and micronutrients using this co-associated, genetic loci. Likewise, the overexpression of HvSUT-1 in wheat led to a significant increase in yield, seed size and an increase in $\mathrm{Fe}$ and $\mathrm{Zn}$ concentration (Saalbach et al. 2014).

Today, several breeding programs within the CGIAR network have biofortification as a core trait and therefore we are assured of new varieties in these programs, having both good agronomic performance and high nutrient concentration. Today, the current global challenge of $\mathrm{Fe}$ and $\mathrm{Zn}$ deficiencies in human populations can be prevented with timely and adequately implemented biofortification strategies which tend to reach the most affected population groups; malnourished rural populations with low dietary diversity, limited access to supplementation and fortified foods (Bouis and Welch 2010). Biofortification has shown itself to be a sustainable strategy aimed at increasing the concentrations of $\mathrm{Fe}$ and $\mathrm{Zn}$ in edible crop plants, reducing the negative consequences of commonly consumed $\mathrm{Fe}$ and/or $\mathrm{Zn}$ deficient crops, alleviating $\mathrm{Zn}$ and $\mathrm{Fe}$ deficiency in people, and intended to help in eradicating the hidden hunger of the growing population by 2030 (United Nations 2016).

With the advent of biofortification came a heightened focus on $\mathrm{Fe}$ and $\mathrm{Zn}$ homeostasis, to further improve our knowledge of the physiology of these two elements and the genetics related to improving $\mathrm{Fe}$ and $\mathrm{Zn}$ nutrition of the edible portion of crop plants. Inherent variation in $\mathrm{Fe}$ and $\mathrm{Zn}$ was exploited within germplasm banks, to try and meet Fe and $\mathrm{Zn}$ targets developed by the nutrition community.

When screening germplasm, questions arose as to the heritability of the trait, versus the effects of environment and whether the genetics were sufficient to enable a breeding program. Concurrently, plant physiologists needed to better understand the mechanisms associated with the transport of more $\mathrm{Fe}$ and $\mathrm{Zn}$ into seeds, tubers, and edible roots. Since the advent of biofortification, there have been numerous reports in the literature around these central themes.

The founding fathers of biofortification, Professor Ross Welch, Professor Robin Graham, and Dr. Howarth Bouis grasped the concept of using agriculture to deliver improved nutrition to an estimated 2 billion people worldwide who are suffering from hidden hunger, where one-third of the global population is affected by Zn and Fe deficiency (Beal et al. 2017). Their foresight has led to a global movement to not only see agriculture as a means to provide caloric energy, but also to provide essential micronutrients. Furthermore, we are now thinking more about the bioavailability of $\mathrm{Fe}$ and $\mathrm{Zn}$ and it not just about their intake. Antinutritional factors and promoters of absorption are on the agenda for genetic manipulation to enhance the absorption of $\mathrm{Fe}$ and $\mathrm{Zn}$ in the human gut.

This review summarises and discusses major challenges, achievements, and benefits gained through $\mathrm{Zn}$ and $\mathrm{Fe}$ biofortification of crop plants made in the last twenty-five years, with more of an emphasis on the cereal crops. It describes the most important approaches used to accomplish $\mathrm{Zn}$ and Fe biofortification goals and discusses promising strategies for effective crop biofortification in the future. Further work is required to ensure that multi-micromineral, nutritionally adequate crops are available in adequate amounts across the globe. While we acknowledge that Vitamin A is also a major deficiency among many in the developing world, this review will focus on $\mathrm{Fe}$ and $\mathrm{Zn}$. 


\section{Biofortification of staple food crops}

The two streams to achieve a biofortified crop are conventional plant breeding and fertiliser agronomy and these complementary routes have been a major accomplishment since the advent of the biofortification strategy (Cakmak 2008; Knez et al. 2018; Saha et al. 2017; Prom-U-Thai et al. 2020; Zou et al. 2019).

Plant breeding

HarvestPlus was borne out of a CGIAR Challenge Program and has a vision of a world free of deficiencies such as $\mathrm{Fe}, \mathrm{Zn}$ and Vitamin A (for a detailed vision, mission and goal statement, see www.harve stplus.org/about/our-mission). HarvestPlus has led the way in terms of the plant breeding strategy, firstly to develop target concentrations across a broad range of crops and then to initiate a breeding approach of first assessing whether stable genetic variability exists for $\mathrm{Fe}$ and $\mathrm{Zn}$ within a crop, and this involved screening germplasm, varieties and elite breeding lines (Andersson et al. 2017). The heritability of micronutrient concentrations in edible plant part was determined for a range of crops as this helps gauge the effect of environment on micronutrient concentration and whether the genetic component was sufficient to allow for a breeding initiative to be successful. In some cases (i.e., wheat), the high $\mathrm{Zn}$ trait was found in wild relatives, and this created a more complex strategy to first bring in the high $\mathrm{Zn}$ alleles across from the wild relatives, such as the making of synthetics which could then be used in the conventional breeding program. As of 2016, HarvestPlus partners had released more than 140 biofortified varieties of 10 staple crops in 26 countries (Andersson et al. 2017).

The progress to date is significant, with 340 biofortified varieties from 12 crops having been released in 40 countries (Fig. 1) and potentially a broader range of crop varieties undergoing testing in various target countries (Fig. 2) (Bouis et al. 2020).

\section{Micronutrient screening}

Accurate and precise micronutrient analysis is essential for a successful biofortification breeding program and major advances in screening for nutrient-dense crops have been realised over the last
20 years. Colorimetric methods are used as a rapid visual tool for screening grain samples in the preliminary stages of the breeding process.

Direct association between the ICP and colorimetric method measurements for $\mathrm{Fe}$ was seen in wheat, rice, and maize and for $\mathrm{Zn}$ in wheat (Choi et al. 2007; Ozturk et al. 2006).

Colorimetric methods are semi-quantitative and therefore are good for screening, but the preparation and staining can be a laborious task and not entirely suitable for a breeding program. Atomic absorption spectrometry (AAS) and Inductively Coupled Plasma - Optical Emission Spectroscopy (ICP-OES) or Inductively Coupled Plasma - Mass Spectrometry (ICP-MS) are optimal analytical methods that give total nutrient levels but are expensive analyses and require high purity chemicals, so are not ideal outside of a very clean laboratory. Energy Dispersive $\mathrm{X}$-Ray Fluorescence (EDXRF) is a low cost, stable, non-destructive, high-throughput, multi-elemental method that requires little or no sample preparation and is appropriate for measuring a wide range of $\mathrm{Fe}$ and $\mathrm{Zn}$ concentrations.

XRF results are highly correlated with ICP-MS analysis in wheat (Paltridge et al. 2012a), rice, pearl millet (Paltridge et al. 2012b), maize and bean (Guild et al. 2017). EDXRF has also been shown as a successful screening technique for the HarvestPlus secondary crops cowpea (Guild et al. 2017), potato (Sosa et al. 2018), lentil and sorghum (Guild and Stangoulis 2021). Being a fast (30-60s per sample) and cheap (less than a US \$2 per sample) analytical method with comprehensively described calibration protocol, developed and optimized custom calibrations for specific minerals, XRF has become the widely used method for quantifying $\mathrm{Fe}$ and $\mathrm{Zn}$ levels in plant samples across various breeding programs. The only disadvantage of this technique is the inability to detect appreciable amounts of the soil contaminants, $\mathrm{Al}$ and $\mathrm{Ti}$, so processing from sampling to analysis should be performed with caution (Stangoulis and Sison 2008).

Going forward, the challenge of maintaining accurate and precise analysis will remain and one can see the need for continual validation of $\mathrm{Fe}$ and $\mathrm{Zn}$-dense varieties in certified laboratories offering analysis. This will be important to ensure quality control. Rapid analysis with mobile, portable XRFs will be a future technology embraced by the consumer market. 


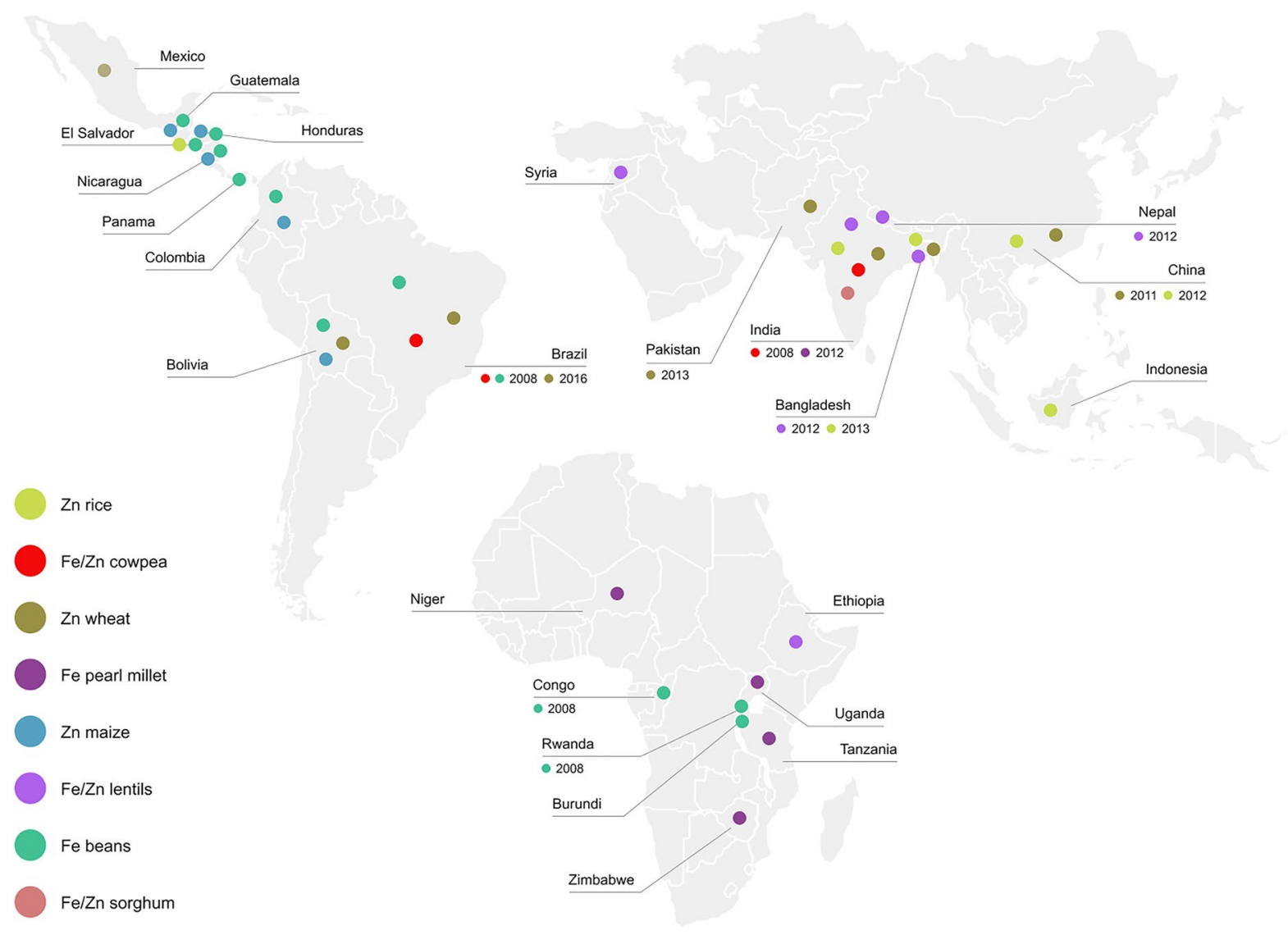

Fig. 1 Fe and Zn biofortified crop varieties released in various countries. Years of the first time released $\mathrm{Zn}$ and $\mathrm{Fe}$ biofortified crops in certain countries are presented. Figure constructed based on data provided by (Raney et al. 2013; Andersson et al. 2017; Bouis et al. 2020)

the parents used in double haploids or other diversity panels may not have a broad and stable range of $\mathrm{Fe}$ and/or Zn and with a large QTL spanning a large segment of a chromosome, it is very hard to identify candidate genes. Genome wide association studies (GWAS) can accelerate development of genetic markers and help in faster identification of genes for biofortification. Gene families involved in $\mathrm{Fe}$ and $\mathrm{Zn}$ transport are multigene families; various genes are expected to be involved in $\mathrm{Fe}$ and $\mathrm{Zn}$ uptake, transport and accumulation, so it is important to identify the most suitable gene family members for biofortification of major crops (Alomari et al. 2019).

Genome-wide association studies include a broader genetic base, they are able to identify many trait marker associations and are used to separate the genetics of diverse populations. Thirty-nine 


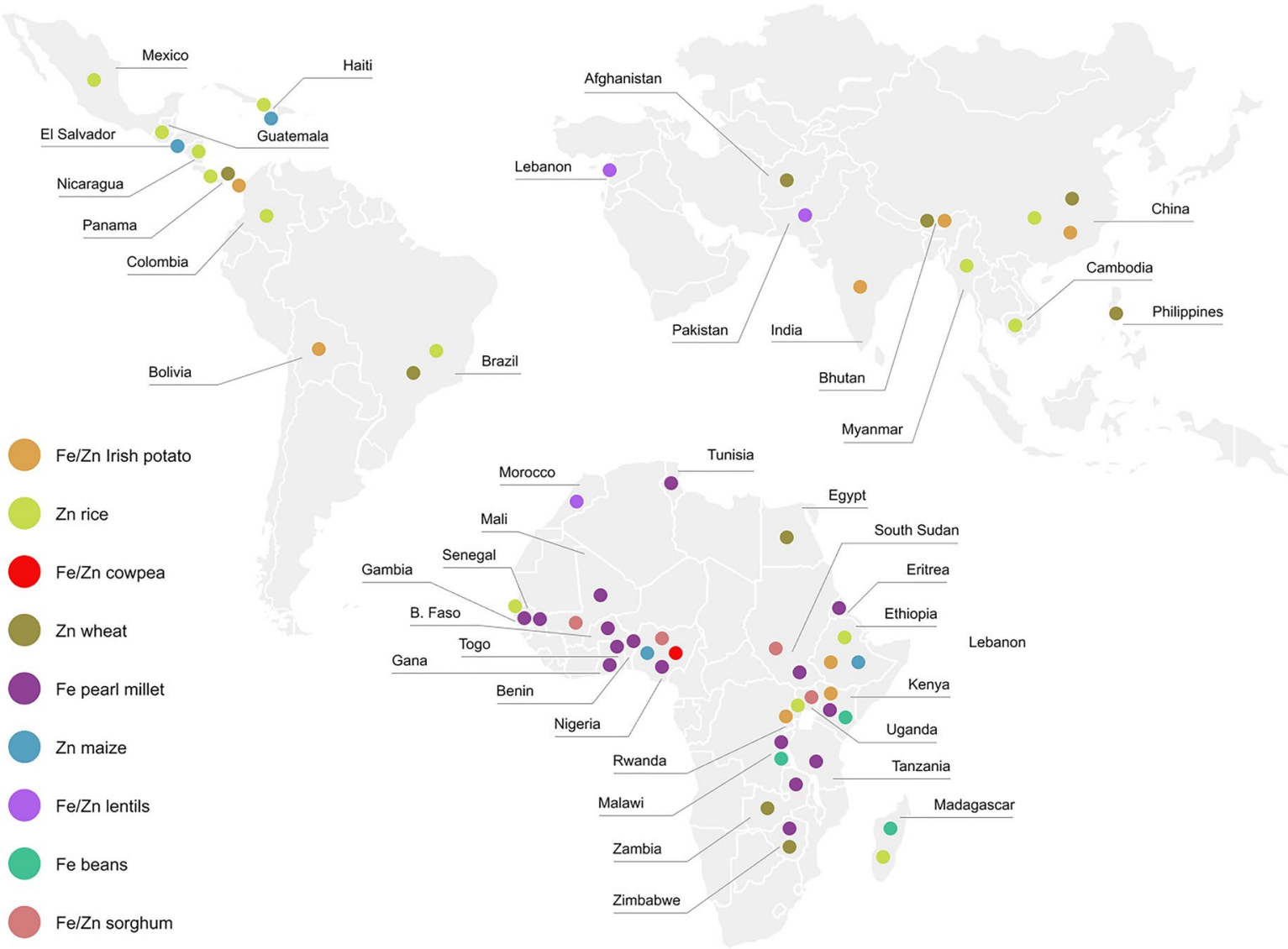

Fig. 2 Currently evaluated Fe and $\mathrm{Zn}$ biofortified crop varieties in several countries. Figure constructed based on data provided by Bouis et al. 2020

marker trait associations were identified for $\mathrm{Zn}$ on chromosomes 2 and 7 (Velu et al. 2018b). As $\mathrm{Fe}$ and $\mathrm{Zn}$ concentration of crops is controlled by a large number of loci, it is currently challenging to implement the findings in breeding programs, so more precision is required to discover the exact regions responsible for $\mathrm{Fe}$ and $\mathrm{Zn}$ concentration and to give an indication of variation in these markers and their potential effectiveness in breeding (Tong et al. 2020). The complete haplotype-block based method could be more effective and practical (Ali and Borrill 2020).

Recent advances in GWAS have allowed for the genetic imputation to increase marker density and resolution (Wang et al. 2018) and this has allowed for a more accurate identification of candidate genes (Wu and $\mathrm{Hu}$ 2021). The use of genomic selection shows great promise for identifying genotypes in breeding programs with moderate to high prediction accuracy for $\mathrm{Fe}$ and $\mathrm{Zn}$ reported across environments (Velu et al. 2016). One can see this technology more readily used in the future.

\section{The complexity of $\mathrm{Fe}$ and $\mathrm{Zn}$ transport to fruit, seeds and tubers}

There are several major regulatory hurdles for Fe and $\mathrm{Zn}$ transport from between the plant root to the shoot and developing fruit, seed or tuber, and these are well covered in several reviews (Bashir et al. 2019; Palmgren et al. 2008; White and Broadley 2011; Puig and Peñarrubia 2009). For root uptake, in brief, plants usually fall into two groups for Fe uptake; Strategy I 
(eudicots) and Strategy II (grasses), where the former utilizes a membrane-bound reductase to reduce $\mathrm{Fe}^{3+}$ to $\mathrm{Fe}^{2+}$, while in the latter we have the efflux of phytosiderophores such as 2'-deoxymugineic acid into the rhizosphere where it complexes to $\mathrm{Fe}^{3+}$ and the phytosiderophore-Fe ${ }^{3+}$ complex is then transported across the plasma membrane into the cytoplasm (Mori 1999). While eudicots and grasses (and cereals of interest in biofortification) appear to fall within the two strategy classes, to date, we seem to have only one known exception to this, where rice also exhibits the Strategy I mechanism, with OsIRT1 and OsIRT2 being the transporters involved in transporting $\mathrm{Fe}^{2+}$ across the plasma membrane (Ishimaru et al. 2006). For $\mathrm{Zn}$ uptake, it can be taken up by root cells as either $\mathrm{Zn}^{2+}$ or as a $\mathrm{Zn}$-phytosiderophore complex. A more detailed description of the transport processes to transport in the xylem and phloem is given in the references above and we will mainly discuss areas where further research is required.

In their review of the physiological limits to $\mathrm{Zn}$ biofortification of edible crops, White and Broadley (2011) conclude that $\mathrm{Zn}$ concentrations in fruit, seeds and tubers are severely limited by $\mathrm{Zn}$ transport in the phloem and there must be an effective way of sequestering the additional metal away so that there are no adverse perturbations in the cytoplasm. Likewise, $\mathrm{Fe}$ retranslocation in the phloem is also a limitation in the delivery to fruit, seeds and tubers. Pearson et al. (1996) were able to show good remobilization of $\mathrm{Zn}$ in wheat, while Garnett and Graham (2005) reported good remobilization of Fe from shoot to grain in well drained wheat, while in contrast, Hocking (1994) reported a very low level of remobilization of Fe in irrigated wheat, highlighting the effect of environment. Rice also shows poor remobilization of $\mathrm{Fe}$ (Marr et al. 1995), while in beans (Zhang et al. 1995) and peas (Grusak 1995) there appears to be good Fe remobilization. There is a clear need to better understand why species variation exists for remobilization, and this will be discussed in subsequent sections.

The activation of senescence is the trigger for remobilization of metal ions to the developing caryopsis and in wheat, the NAM-B1 gene has been implicated in this process as it is a part of the mechanism that stimulates remobilization of metal ions from the vegetative tissues and their directional transport to the developing seed (Waters et al. 2009). The on-going feed-forward control of seed nutrient loading into seeds is thought to be regulated by nutrient levels reaching the developing seed, however the feedback control generated by filial demand is less well understood. It is thought to involve transmission of regulatory signals from sites of metabolism/compartmentalisation within developing filial tissues. These signals then control nutrient transport and transfer processes located along the source/path/sink system (Zhang et al. 2007). This control could be open to and mediated by signals outside of nutrient flows (i.e., hormones), or closed and mediated directly by plant tissue nutrient levels.

Currently, we know little about the relationship between hormone signalling and micronutrient supply from source to sink. We do know that auxin concentration in developing grain correlates with grain filling rate in rice (Xu et al. 2007) and wheat (Liu et al. 2013) with cytokinin levels also showing positive links to maximum grain weight and grain filling rates in wheat (Liu et al. 2013). There is a need for more research in this area.

As an example of a closed loop system that's mediated by nutrient levels, there is the increase in filial demand for Fe by the expression of soybean ferritin in rice seed, leading to increased Fe deposition within the endosperm (Qu et al. 2005). Zhang et al. (2007) hypothesised that the increased supply of Fe may be derived from source tissues after a signalling pathway is activated by depletion of Fe in the filial cytoplasm. Again, more information on the signalling pathway is required for a targeted approach in plant breeding.

Genotypic variation in filial growth rates appears to be linked to differences in $\mathrm{Zn}$ accumulation within wheat (Stomph et al. 2011). Grain protein levels have also been implicated in providing the sink strength (Kutman et al. 2011) and delivery of amino acids is also dependent on their delivery via the phloem. We know little about the proteins binding $\mathrm{Zn}$ and $\mathrm{Fe}$ within sink tissues and more definitive studies are needed in this area. (Hegelund et al. 2012) reported metallothionein's in barley filial tissues and they are known to bind $\mathrm{Zn}$. A question arises as to whether natural variation exists for $\mathrm{Zn}$ and Fe binding proteins and whether this could help to explain subtle differences in $\mathrm{Fe}$ and $\mathrm{Zn}$ content. Furthermore, whether they could be chemical species for further genetic manipulation to help improve the bioavailability of the nutrients. 
Abiotic and biotic stressors negatively impact on photosynthetic activity and sucrose levels in leaves (Rosa et al. 2009), and this in turn impacts on the delivery of both photo-assimilate and micronutrients to developing seeds. Also, with climate change, there is a greater incidence of extreme events (Lobell and Gourdji 2012), including heat and drought stress (Lobell et al. 2012), and this has the potential to impact on nutrient uptake and nutrient delivery to fruits, seeds and tubers.

There is a need to better understand the complex phloem signalling relationship and to identify genotypes with efficiency and tolerance mechanisms that lead to maintaining adequate carbon fixation and phloem photoassimilate/micronutrient levels.

There are commonalities between cereal species targeted for biofortification when it comes to long distance transport. Simply, xylem is unidirectional and will provide the water and nutrients while the phloem is bidirectional and delivers photoassimilate and nutrients to various tissues to maintain growth and metabolism. Plant structural differences do exist between species and even within a species we have differences in growth and nutrient requirements. One such anomaly found between species is the xylem discontinuity (Thorne 1985; Zee and O'Brien 1970).

Fundamentally, a nutrient entering the seed must first be transported from the xylem to the phloem before it is translocated to the developing reproductive tissues of crops such as wheat, barley and oats. Rice, however, has a continuous xylem and the vascular bundle is located around the circumference of the seed (Thorne 1985). Therefore, the long-distance transport characteristics in rice are dissimilar to many of the other cereals. In rice, there is a direct route (for root derived $\mathrm{Zn}$ ) transported to the developing caryopsis via the xylem, coupled with xylem to phloem transfer at stem and panicle nodes (Nishiyama et al. 2013; Yoneyama et al. 2010). Also, unlike other cereals, rice has a mechanism of relatively uniform deposition of $\mathrm{Zn}$ throughout the endosperm, the loss due to polishing is around only $10-15 \%$ of total grain $\mathrm{Zn}$ (Jaksomsak et al. 2018). In contrast, Fe in rice mostly accumulates in the aleurone layers and embryo (Kyriacou et al. 2014). Structural anomalies within the seed also exist and appear to influence the $\mathrm{Fe}$ and $\mathrm{Zn}$ distribution within the seed. In wheat and barley, the grain crease runs the length of the seed kernel, and a single vascular bundle is embedded within the maternal pericarp. In rice, there is a singular vascular bundle embedded within the pericarp, but nearer the outer grain surface (Thorne 1985). Wheat and rice unload assimilates over the full length of the bundle and when given excess $\mathrm{Zn}$, in wheat it accumulates this excess $\mathrm{Zn}$ in the crease region (Stomph et al. 2011). A transport barrier to the endosperm appears to be present at the endosperm cavity. In rice, the vascular bundle is located around the circumference of the seed and on unloading, there is symplastic transport through the plasmadesmata, to the nucellus and transport into the aleurone and then the endosperm. The endosperm cavity is not present, and this is one less obstacle for the movement of nutrient. Also, in close proximity to the phloem in rice is the xylem vessel, and what role that plays in the delivery of $\mathrm{Zn}$ (in particular) needs further research.

In the rice phloem, $\mathrm{Fe}$ and $\mathrm{Zn}$ chelate mostly to 2'-deoxymugineic acid and nicotianamine, respectively (Nishiyama et al. 2012). There is some suggestion that not all rice genotypes can remobilise $\mathrm{Zn}$ (Impa et al. 2013), where the authors found that under Zn-sufficient conditions there was continued root uptake during the grain filling stage and this was the major source of $\mathrm{Zn}$ unloading into the rice grains, a finding also supported by (Jiang et al. 2007), whereas under $\mathrm{Zn}$ deficiency, a number of genotypes remobilised $\mathrm{Zn}$ from shoot to root and then back to the grain, but not all genotypes did this.

Further physiological studies across a broader range of genotypes that differ in their seed $\mathrm{Zn}$ at maturity is required as this may aid in plant breeding.

The future potential of biotechnology

Modern biotechnology tools can be used for the development of biofortified crops. Low-cost, highspeed technologies that enable the discovery of nontargeted genes and alleles have been established (Carvalho and Vasconcelos 2013).

Various genomics and molecular breeding approaches i.e., marker-assisted selection, highthroughput phenotyping, and genotyping for selecting particular traits could be incorporated into genetic engineering and breeding programs designed for $\mathrm{Fe}$ and $\mathrm{Zn}$ biofortification strategies (Ricroch and Hénard-Damave 2016). Reverse-breeding, oligodirected mutagenesis, 'genome editing' - sequencespecific nuclease technology, and high-throughput 


\section{Fe / Zn Biofortification Approaches}

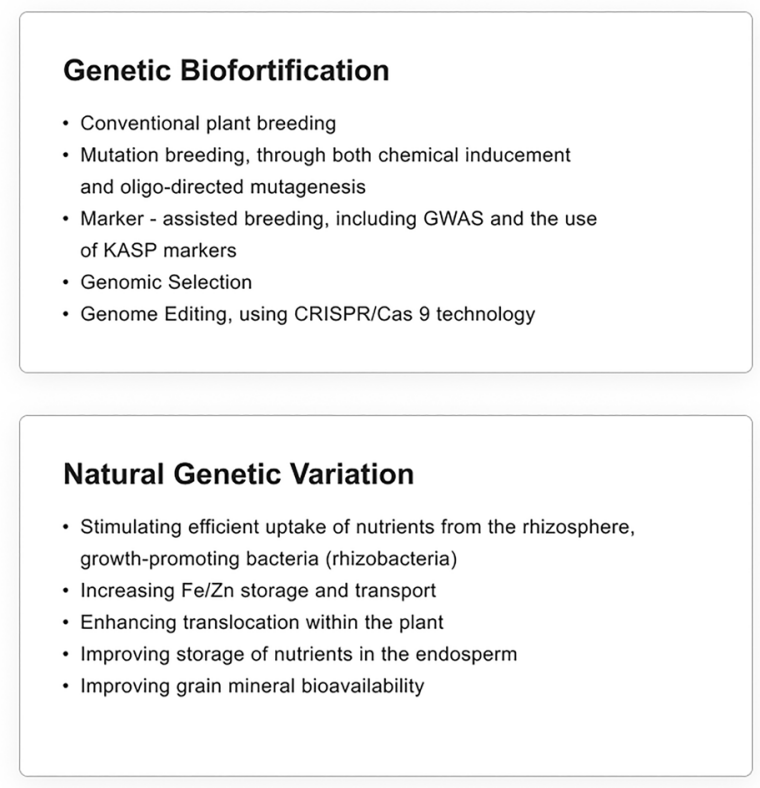

\section{Agronomic Approaches}

- Mycorrhizal inoculation, AMF

- Fertilizers

- Foliar Fe/Zn fertilization

- Optimizing nitrogen fertilizer application

- Crop rotations

Fig. 3 Summary of strategies used for Fe and Zn biofortification of crop plants

phenotyping are all-new, modern technologies (Fig. 3) that could provide significant advances in micronutrient biofortification strategies by allowing mixing increased concentrations of minerals and/or promotive compounds with decreased levels of antinutrients (Vasconcelos et al. 2017).

Genetic engineering has a role to play in improving the nutrition of the edible portion of a cultivar, by allowing manipulation of a particular gene. Certain transporters/gene families were used to produce transgenics for $\mathrm{Fe}$ and $\mathrm{Zn}$ biofortification in rice and wheat (Trijatmiko et al. 2016; Singh et al. 2017). New Zn enriched biofortified wheat cultivar, BARI Gom 33, resistant to wheat blast and other common diseases, was recently produced (Barma et al. 2019). Expression of OsHMA1 has an important role in $\mathrm{Zn}$ transportation, root to shoot translocation, and is highly upregulated in shoot tissues under $\mathrm{Zn}$ deficiency ( $\mathrm{Li}$ et al. 2015). OsHMA1 expression was seven times higher in Zn-deficient tissues, compared to Zn-sufficient conditions (Suzuki et al. 2012). OsNAC5 and OsIDEF1 genes play a role in metal remobilisation, and they are overexpressed for improving Fe concentrations (Kobayashi et al. 2010; Ricachenevsky et al. 2013). Expression of rice nicotianamine synthase ( $O s \mathrm{NAS} 2$ ) and soybean ferritin (SferH-1) genes contributed to endosperm $\mathrm{Fe}$ and $\mathrm{Zn}$ enhancement (Johnson et al. 2011; Trijatmiko et al. 2016) and this was achievable in controlled field grown conditions, in a research station (Trijatmiko et al. 2016). Overexpression of NAS was also linked to overexpression of Fe transporters (Boonyaves et al. 2017).

Transgenic rice lines overexpressing the Fe (II)nicotianamine transporter OSYSL2 and Fe storage protein ferritin contained higher concentrations of both $\mathrm{Zn}$ and $\mathrm{Fe}, 1.6-$ and 6-fold increase, respectively. The introduction of several genes was much more efficacious in increasing the $\mathrm{Fe}$ and $\mathrm{Zn}$ concentrations than the inclusion of a single gene (Masuda et al. 2012). The over-expression of ferritin increased $\mathrm{Fe}$ accumulation in rice and wheat grain seeds even when plants were grown under Fe deficient conditions (Borg et al. 2012; Masuda et al. 2013).

Interestingly, an increased expression of Fe transport and storage proteins improved both $\mathrm{Fe}$ and $\mathrm{Zn}$ concentrations in transgenic rice, 3.4 and 1.3 folds, correspondingly (Aung et al. 2013). A twofold increase in $\mathrm{Fe}$ concentrations was seen when 
a vascular Fe transporter was expressed under an endosperm-specific promoter (Connorton et al. 2017).

Transgenic high yielding Indica rice with an expressed ferritin gene from soybean provided a 2.54 increase in $\mathrm{Fe}$ and 1.54 increase in $\mathrm{Zn}$ concentration (Paul et al. 2014). Transgenic rice plants that expressed 2'-deoxymugenic acid (DMA) and nicotianamine collected up to 4-fold more $\mathrm{Fe}$ and 2-fold more $\mathrm{Zn}$ in the endosperm (Banakar et al. 2017).

While the enrichment of grain endosperm with $\mathrm{Fe}$ and $\mathrm{Zn}$ by the use of molecular strategies is becoming increasingly popular within the research community, biotechnological tools to increase not only the concentration but also the bioavailability of minerals in crops needs consideration.

Bioavailability refers to the relative amount of a micronutrient that is absorbed in the human gut from a certain crop plant, and it depends on several external and internal factors and intestinal digestion, so the exact determination of bioavailability of a nutrient in a plant part is not a straightforward process. In crops, $80 \%$ of phosphate is in the form of phytic acid accumulated in the seeds (Bohn et al. 2008). Phytic acid is a strong indicator of bioavailability, a ratio of $<1: 1$ phytic acid: Fe, without any enhancers of $\mathrm{Fe}$ absorption, or phytic acid: $\mathrm{Zn}$ $<1: 15$ is needed for improved absorption of $\mathrm{Fe} / \mathrm{Zn}$ from crop plants (Gibson 2006; Hurrell and Egli 2010). However, the bioavailability of micronutrients is not entirely attributed to phytic acid levels as in certain crops QTL for total Fe concentration in grain is overlapping with the QTL for Fe bioavailability in grain (Lung'aho et al. 2011). Similarly, it was shown that increasing the content of NA or overexpression of NAS gene enhances Fe bioavailability in wheat and maize (Beasley et al. 2019). Overexpression of NAS is shown to be a promising approach for improving bioavailability of $\mathrm{Fe}$ and $\mathrm{Zn}$ (Clemens 2019). High throughput technologies can be used in this instance and could produce much faster and more efficient effects (Wang et al. 2014). For instance, during heating procedures, Fe (III) hydroxide in ferritin is transformed to $\mathrm{Fe}^{2+}$ or $\mathrm{Fe}^{3+}$ and chelated with phytates in the food matrix (Hoppler et al. 2008).

Exome sequencing of $\mathrm{Fe}$ and $\mathrm{Zn}$ homeostasislinked genes in germplasm, transcriptome profiling, and genome engineering technologies could be used to obtain data on the best possible allelic variants of target genes to design novel varieties of biofortified crops (Abdallah et al. 2015; Vasconcelos et al. 2017). Extended shelf life, enhanced yield, improved nutritional value and decreased antinutritional factors in crops are agronomic traits that could be modified with genome editing (Abdallah et al. 2015). New technologies allow for biofortification of amino-acids and manipulations in fatty acid content of crop grains (Che et al. 2016).

The success of agronomic research

Foliar fertiliser application is generally seen as a way of overcoming low grain nutrient concentrations caused by immobilization of a mineral in the soil (Fig. 3) (Duxbury et al. 2006). Through leaves, plants absorb $\mathrm{Fe}$ and $\mathrm{Zn}$ and in theory that would lead to improved absorption at the point of utilization; in growing tissues (Khoshgoftarmanesh et al. 2010). Within the stem and leaf tissue, nutrients can then be transported via phloem or xylem (Rengel et al. 1999) and application at specific plant growth times can improve grain $\mathrm{Fe} / \mathrm{Zn}$ content and enhance yield when deficiency is present (Cakmak et al. 2010a; Cakmak and Kutman 2018; Farooq et al. 2012; Graham et al. 1992; Graham et al. 1997; Graham et al. 2007; Kiran et al. 2021). Modification of the soil properties, by using animal manure and plant residues has also been shown to increase $\mathrm{Fe}$ and $\mathrm{Zn}$ availability (Prasad et al. 2014) but foliar application appears to be much more effective than non-foliar, soil nutrient application in the enhancement of grain concentrations of nutrients. Yet, the effectiveness of foliar application is crop specific, with rice showing site differences in the efficacy of foliar applied $\mathrm{Zn}$ (Prom-U-Thai et al. 2020; Wei et al. 2012), whereas for wheat, foliar applications of $\mathrm{Zn}$ is very effective in increasing grain $\mathrm{Zn}$ across different environments. For example, a $\mathrm{Zn}$ foliar application of $0.5 \% \mathrm{ZnSO}_{4}$ increased $\mathrm{Zn}$ concentration of wheat grains by $95 \%$ and bioavailability by $74 \%$ (Hussain et al. 2012). Increased transport of nutrients from leaves into seeds was attained via spraying $0.5 \% \mathrm{Zn}$ solution and grain $\mathrm{Zn}$ concentration doubled (Peck et al. 2008). Similarly, the application of $\mathrm{Fe}$ fertilisers via foliar feeding enhanced Fe uptake and translocation (Velu et al. 2014; Wei et al. 2012). Different fertilizers, both organic and inorganic $\mathrm{Zn} / \mathrm{Fe}$ salts have a crucial role in the 
transport of micronutrients from leaves to the grain (Colle et al. 2009). The timing of foliar application is important as it determines the effectiveness of unloading optimal amounts of nutrient into grains (Cakmak et al. 2010b). In wheat, the milk to grain filling stages are the most effective periods for biofortifying grains with $\mathrm{Zn}$ (Cakmak et al. 2010b; Ozturk et al. 2006; Yang et al. 2011), with good enrichment predominantly in the aleurone and embryo (Cakmak et al. 2010b). Foliar applications of fertiliser in the grain maturation stage, near harvesting appears to be very efficient as starchy endosperm absorption is up to three-fold and the phytate concentration is at a sub-optimal level (Velu et al. 2014). Das et al. (2019) reported that an optimal time for increasing grain mineral concentration was achieved with a combination of foliar application of $\mathrm{Zn}$ after anthesis, plus a soil mineral application (Das et al. 2019). Knez et al. (2018) developed $\mathrm{Zn}$ biofortified wheat grain by a foliar application of $1.5 \mathrm{~L} \mathrm{ha}^{-1} \mathrm{ZnSO}_{4}$ during the mid-vegetative growth stage followed by $2 \mathrm{~L} \mathrm{ha}^{-1} \mathrm{ZnSO}_{4}$ two weeks after flowering. The mid-vegetative application was used to mitigate any effect of $\mathrm{Zn}$ deficiency, a common occurrence in the high $\mathrm{pH}$ soils of the Wimmera region of Victoria, Australia. Interestingly, the high $\mathrm{Zn}$ flour had a $\mathrm{Zn}$ and Fe concentration of $47.2 \mathrm{mg} \mathrm{kg}^{-1}$ and $58 \mathrm{mg} \mathrm{kg}^{-1}$ respectively, while the low $\mathrm{Zn}$ flour had $33.6 \mathrm{mg} \mathrm{kg}^{-1}$ and $53 \mathrm{mg} \mathrm{kg}^{-1}$ correspondingly, indicating that in wheat, and given careful consideration of fertiliser application timing, one can not only raise the levels of $\mathrm{Zn}$ but also Fe. This differential in $\mathrm{Zn}$ was sufficient to affect $\mathrm{Zn}$ bioavailability and the $\mathrm{Zn}$ status of the chickens in a feed study (Knez et al. 2018) that also altered the gut microbiome (Reed et al. 2018). Optimal times in applying foliar sprays of $\mathrm{Zn}$ appear to be closely linked to optimal concentration in the phloem feeding the developing wheat caryopsis, that being around 9-21 days after anthesis (Palmer et al. 2014).

The effectiveness of biofortified products to improve $\mathrm{Zn}$ nutritional status of animal (including human) subjects has been tested over the years. Welch et al. (2005) were the first to demonstrate the beneficial effect of $\mathrm{Zn}$ biofortified wheat in improving $\mathrm{Zn}$ status of rats. Comparable results were reported by Rosado et al. (2009) in humans and Carlson et al. (2012) in pigs, with the highest concentration of $\mathrm{Zn}$ seen in subjects fed the diets with the highest $\mathrm{Zn}$ concentration; consumption of $\mathrm{Zn}$ biofortified varieties of certain crops improved $\mathrm{Zn}$ status.

Similar findings were provided for Fe biofortified crops, consumption of Fe enriched foods improved $\mathrm{Fe}$ levels of consumers. In addition, protective effects of Fe biofortified foods on animal gut microbiota were shown, provision of Fe biofortified crops increased the presence of beneficial and decreased the abundance of potentially pathogenic bacteria in the gut (Reed et al. 2017; Reed et al. 2018; MoraisDias et al. 2018; Beasley et al. 2020).

\section{Challenges - soil deficiency}

The bioavailability of a nutrient in the rhizosphere is well studied and in part is affected by clay content, cation exchange capacity, the content of soil organic matter, and soil pH (Marschner 2012; Nguyen and Marschner 2017; Ramzan et al. 2014). Arguably, the most widespread micronutrient deficiency in the world today is $\mathrm{Zn}$ deficiency, observed in more than $50 \%$ of investigated soils with deficiency rates ranging from $48 \%$ up to $86 \%$ (Dharejo et al. 2011; Manyevere et al. 2017; Reza et al. 2017; Shukla et al. 2017; Singh et al. 2005). Only $10 \%$ of $\mathrm{Zn}$ is available to plants (Alloway 2009).

$\mathrm{Zn}$ and $\mathrm{Fe}$ concentrations in the grains are strongly linked to the inherent $\mathrm{Zn}$ and Fe capacity of the soils, so a suitable level of water and minerals in the soil during the reproductive stage of plant development is needed for adequate grain nutrient concentrations (Cakmak and Kutman 2018). An indirect correlation is seen between $\mathrm{Fe}$ and $\mathrm{Zn}$ and cation exchange capacity of the soil (Yoo and James 2002). The higher the exchange capacity, the lower the availability of $\mathrm{Fe}$ and $\mathrm{Zn}$.

Native soil $\mathrm{Zn}$ status and its physiochemical properties are determining factors of rice grain $\mathrm{Zn}$ concentrations (Wissuwa et al. 2008). Rice grain $\mathrm{Zn}$ concentrations could range from 8 to $47 \mathrm{mg} / \mathrm{kg}$, depending on the soil status. The use of soil applied fertilizers cannot compensate for the low accessibility of $\mathrm{Zn}$ in the soil, while the addition of fertilizers increased straw $\mathrm{Zn}$ concentrations and improved straw and grain yield, but grain $\mathrm{Zn}$ concentrations remained unchanged or were only slightly elevated, 
irrespective of genotype (Duxbury et al. 2006; Wissuwa et al. 2008). An application of $\mathrm{Zn}$ as a foliar spray during the early-grain filling stage could be helpful as it has been shown that it increased $\mathrm{Zn}$ concentrations from 3.7 to 5.6-fold in peas and $\mathrm{Zn}$ concentration to $60 \mathrm{mg} \mathrm{Zn} / \mathrm{kg}$ (Poblaciones and Rengel 2016). High concentrations of $\mathrm{Zn}$ in roots and leaves can be accomplished with soil $\mathrm{Zn}$ fertilizers (Wei et al. 2012).

\section{The rhizosphere effect and biofortification}

The uptake of $\mathrm{Fe}$ and $\mathrm{Zn}$ into the root and their longdistance transport have been extensively reviewed over recent years (Palmgren et al. 2008; Puig and Peñarrubia 2009; White and Broadley 2011) and we are well aware of the importance of the rhizosphere in the supply of $\mathrm{Fe}$ and $\mathrm{Zn}$ for root uptake.

The rhizosphere environment is dynamic and has a direct influence on plant growth and yield (Hakim et al. 2021). Basically, a $\mathrm{Zn} / \mathrm{Fe}$ deficient rhizosphere gives nutrient deficient plants (Welch and Graham 2005), and the effect of soil textural properties greatly impacts on the availability of Fe and $\mathrm{Zn}$ in the soil solution, and hence the availability for scavenging by plant roots. Having a role in nutrient availability and maintenance of plant health, is the microbiome (Berendsen et al. 2012; Lehmann et al. 2014) and this will be discussed in more detail as it is an area that shows potential for genetic manipulation to improve nutrient availability and uptake into the edible portion of the crop plant.

Growth-promoting bacteria are essential components of the rhizosphere (Chandra et al. 2020). Root colonizing rhizobacteria have been shown to stimulate plant growth, grain protein content, yield, and nutrient uptake in plants (Rodrigues et al. 2008; Sharma et al. 2011). Their presence improves the soil structure, aeration, and fertility, suppresses the growth of pathogens, and improves plant immunity (Hakim et al. 2021). Inoculation of soils or crops with rhizospheric microbes is shown to enhance the content of $\mathrm{Fe}$ and $\mathrm{Zn}$ in plant tissues ( $\mathrm{Ku}$ et al. 2019).

Microorganisms within the rhizosphere help to provide soluble forms of essential nutrients (Szymańska et al. 2016). Additionally, plant growth-promoting rhizobacteria and endophytic bacteria contribute to growth-promoting activities such as the formation of root nodules, solubilization of minerals, reduction of negative effects of certain pathogens, phytohormone production, and degradation of xenobiotic composites (Chandra et al. 2020). Rhizospheric microbes can be a useful strategy for increasing the concentrations of micronutrients in edible parts of crops plants. Further research is required to explore the physico-chemical characteristics of the rhizosphere, to identify new microbial communities and to explore plant-nutrientrhizobacteria interaction.

The effect of mycorrhizal inoculation is also of interest as an agronomic intervention strategy to improve the nutrition of food products, such as seeds. With widespread nutrient deficiencies throughout many of the world's arable soils, mycorrhiza could help mitigate sub-optimal supply of $P$ and micronutrients such as $\mathrm{Zn}$. In a comprehensive meta-analysis on 104 articles comprising 263 trials to test the influence of 10 independent variables on arbuscular mycorrhizal fungi (AMF) - mediated Zn concentration, in comparison to non-mycorrhizal controls, AMF had a positive overall impact on $\mathrm{Zn}$ concentration in above ground plant tissues, fruit and seed tissue (Lehmann et al. 2014). A very clear impact of mycorrhiza was reported by (Ercoli et al. 2017), showing an effect of AMF inoculation on $\mathrm{Fe}$ and $\mathrm{Zn}$ in field grown durum wheat. (Lehmann et al. 2014) in their meta-analysis identified soil texture as modulating AMF, with soil $\mathrm{pH}$ and soil Zn concentration affecting AMF-mediated shoot $\mathrm{Zn}$ concentration and soil $\mathrm{P}$, influencing fruit $\mathrm{Zn}$ concentration. The environmental conditions therefore play a major role in the efficacy of AMF inoculation. Variable gains by AMF as witnessed in wheat and barley by (Coccina et al. 2019) could also be explained by choosing genotypes with variable efficiency in phloem retranslocation and unloading into the caryopsis. The authors found that the mycorrhizal pathway of $\mathrm{Zn}$ uptake contributed up to $24.3 \%$ of total above-ground $\mathrm{Zn}$ in wheat, and up to $12.7 \%$ of that $\mathrm{Zn}$ in barley. Their results suggest that AMF has a substantial role in uptake of $\mathrm{Zn}$ into cereals and the proportional contribution by the mycorrhizal pathway of uptake is dependent on plant species, as well as available soil Zn. Similarly, a recently published paper by Yazici et al. (2021) showed that AMF impairments decreased shoot and grain $\mathrm{Zn}$ concentrations and increased cadmium build-up in wheat plants while mycorrhizal replenishment 
and colonisation promoted shoot and grain $\mathrm{Zn}$ accumulation.

Further research should concentrate on finding out the most efficient methods of mineral application to promote uptake and to maximize the accumulation of $\mathrm{Fe} / \mathrm{Zn}$ in all edible parts of crop plants. Microbial and genomic assisted agronomic strategies may provide a long-lasting solution, but this entails further investigation.

Nitrogen application results in enhanced nutrient deposition in grains

Grain quality is strongly linked to the availability of higher doses of $\mathrm{N}$ in the late reproductive phase of plant development, and a plant's $\mathrm{N}$ status influences the uptake, transport, and relocation of nutrients within the plant tissue (Palmer and Guerinot 2009). Increased $\mathrm{N}$ levels improve the root uptake and passage of $\mathrm{Zn}$, consequently increasing the deposition of $\mathrm{Zn}$ in seeds (Cakmak et al. 2010c). A link to an effect of $\mathrm{N}$ on phytosiderophore release has been made, with an increase in $\mathrm{N}$ supply being very effective in improving the release of phytosiderophores from roots, improving the mobilisation, root uptake, and shoot transport of $\mathrm{Fe}$ in $\mathrm{Fe}$ deficient wheat plants (Aciksoz et al. 2011). Phloem loading, phloem to xylem exchange, deposition of nutrient into grain, depends on nutrient transporter proteins, which activity is enhanced by the addition of $\mathrm{N}$ (Palmer and Guerinot 2009). Also, with increased N application, an enhanced synthesis of long-distance transport compounds such as nicotianamine and 2'-deoxymugineic acid would provide the chelate for long-distance transport. A study that utilizes appropriate phloem collection techniques, such as aphid stylectomy, coupled with metabolite analysis, would be beneficial in further understanding the effect of elevated $\mathrm{N}$ on increased $\mathrm{Zn}$ deposition in grains.

\section{Crop rotations to maintain a biofortified crop}

Crop rotation methods are an integral part of sustainable agriculture, however limited information is available on their role in the quality of the edible portion of the crop, including the nutrient concentration. If considering the effect of $\mathrm{N}$ on seed $\mathrm{Zn}$ and $\mathrm{Fe}$ (see previous section), then a role for rotation in maintaining $\mathrm{N}$ supply to crop plants and thereby maintaining a balanced nutrition, is a worthwhile consideration.

Cereal-cereal rotations have been shown to cause nutrient imbalance, soil degradation, and a deterioration in crop productivity (Chauhan et al. 2012). In contrast, diverse crop rotations help enhance soil quality by improving soil structure, levels of soil organic matter, and mycorrhizal milieu (Hobbs et al. 2008; Plenchette et al. 2005). Similarly, rotations improve plant productivity by increasing nutrient use efficiency and the general quality of grains (Mady Kaye et al. 2007). The incorporation of leguminous plants in crop rotations is an efficient practice for improving the nitrogen cycle in conventional breeding systems (Kubota et al. 2018). Meta-analysis data show that a replacement of bare fallow with legume crops provides benefits as rotation decreases nitrate leakage by $40 \%$ (Tonitto et al. 2006). When legumes were included in rotations, the nitrogen $(\mathrm{N})$ input of subsequently grown crops was much higher (St. Luce et al. 2016). Similarly, post-harvest cover crops are preserving satisfactory soil environments, the use of two winter cover crops in summer crop farming regions improved the yield and $\mathrm{N}$ uptake (Gabriel et al. 2016). Diversification with pulse compost increased water accessibility for subsequent crops (Gan et al. 2015).

The inclusion of pulses in wheat-maize rotation improved soil organic carbon and bioavailability of micronutrients (Venkatesh et al. 2017). Pulses could be a suitable solution for modification and escalation of cereal-cereal rotations. The inclusion of pulses positively affects the nutrient cycle in the soil-plant system due to its impact on soil residual fertility and acquisition of minerals by subsequent crops (Venkatesh et al. 2017).

The advantages of raw and forage crop rotation on yield and mineral concentration in maize showed that two years rotation with maize-soybean-spring wheat and three years rotation with maize-soybeanoat/pea hay plus alfalfa increased yield and kernel phosphorous and potassium concentrations (Riedell and Osborne 2017). Rotations with deep-rooted forage crops i.e., alfalfa increased $\mathrm{N}$ availability and the yield of shallow-rooted crops like maize (Ma and Zheng 2018; Riedell et al. 2009).

The sustainable production of crops requires an improved understanding of the potential beneficial effects of diverse crop rotations. New strategies 
for improving soil health, sustainability, and crop throughput via crop rotation mechanisms merit additional attention and further work.

\section{How to introduce Fe and Zn-dense biofortified varieties?}

A major challenge in the future is maintaining high Fe and $\mathrm{Zn}$ in a biofortified variety, once released to farmers. A reduction in concentration can happen for various reasons, including the mixing of seed (biofortified and non-biofortified) and poor agronomic practices, including fertilizer management. Biotic and abiotic stress can also impact on final $\mathrm{Fe}$ and $\mathrm{Zn}$ concentrations in the edible portion of a crop, and linked to this is research of climate change effects on seed nutrition that also indicate significant changes (Myers et al. 2014). A recent failure of biofortified beans to reach levels of $\mathrm{Fe}$ above locally grown varieties sourced from the market-place in East Africa (Glahn et al. 2020), is further evidence that there is a need to continually monitor biofortified varieties and to provide ways to mitigate perturbations in nutrient concentration. There is obviously a need to better understand local farmer seed systems.

In the marketplace, $\mathrm{Fe}$ and $\mathrm{Zn}$ concentration can be monitored using rapid analysis devices, such as portable XRF instruments. Plant breeders have developed a biofortified variety based on a tried-and-true formula of sourcing $\mathrm{Zn}$ and $\mathrm{Fe}$-dense progenitors and crossing to parents of good agronomic performance, developing large populations and through selection, maintaining nutrient-dense genotypes through the generations. Breeders also conduct multi-location trials and make selections on performance against local checks, but often sites are well maintained, and a farmer may not have the same resources. Irrespective of whether the genetics of a new biofortified variety is sufficient to deliver a stable $\mathrm{Fe}$ or $\mathrm{Zn}$ end-product, the environment where that biofortified variety grows, can still have an impact on final product concentrations.

From a plant nutrition viewpoint, there are a number of reasons why a biofortified product may not meet its target in a farmer's field and one needs to appreciate the importance of a continued $\mathrm{Fe}$ and $\mathrm{Zn}$ availability in the soil solution for root uptake and long-distance supply to developing sinks within the plant. Efficiency in root uptake is of paramount importance, and when one considers the levels of macro and micronutrient deficiency worldwide, many of the target farmers in developing countries are poor and unable to afford costly inputs, to mitigate the effects of deficiency.

\section{Conclusions}

To sum up, $\mathrm{Fe}$ and $\mathrm{Zn}$ enrichment of grains in many crops has already been achieved. Novel biofortification programs and strategies need to be developed to tackle micronutrient insufficiency in crops, particularly considering new environmental constraints. Microbe-mediated biofortification has great potential and warrants further research. New technologies should aim to enhance genotypes that could be used in biofortification programs and to additionally develop techniques for faster breeding, dissemination, and implementation of $\mathrm{Fe}$ and $\mathrm{Zn}$ enhanced cultivars. Finally, the mineral nutritional quality of food crops should aim to encompass all major macro, micro, and antinutrients. There is a need to integrate more micronutrients and broaden biofortification projects beyond $\mathrm{Zn}$ and $\mathrm{Fe}$. Additional regulations are needed to address public safety concerns, ensure adequate monitoring and implementation of transgenes in biofortified crops, and illuminate the effect of transgenic crops on human health. Biofortification efforts of major crop plants should be augmented to respond to new nutrition and health challenges related to the double burden of malnutrition and address the need for diverse and sustainable diets with a maximum beneficial impact around the world. Collaboration between different parties, plant breeders, farmers, consumers, scientists from various disciplines, and national and international organisations and governments is of crucial importance in this instance. Finally, biofortification strategies should be well incorporated in the nutritional agendas so that a vision of reaching 9 billion people by 2030 can turn into a reality.

Acknowledgements We dedicate this review to Professor Dr. Robin Graham who had a guiding influence in Plant Nutrition and Biofortification research, worldwide.

Funding Open Access funding enabled and organized by CAUL and its Member Institutions. 
Open Access This article is licensed under a Creative Commons Attribution 4.0 International License, which permits use, sharing, adaptation, distribution and reproduction in any medium or format, as long as you give appropriate credit to the original author(s) and the source, provide a link to the Creative Commons licence, and indicate if changes were made. The images or other third party material in this article are included in the article's Creative Commons licence, unless indicated otherwise in a credit line to the material. If material is not included in the article's Creative Commons licence and your intended use is not permitted by statutory regulation or exceeds the permitted use, you will need to obtain permission directly from the copyright holder. To view a copy of this licence, visit http://creativecommons.org/licenses/by/4.0/.

\section{References}

Abdallah NA, Prakash CS, McHughen AG (2015) Genome editing for crop improvement: challenges and opportunities. GM Crops Food 6:183-205. https://doi.org/10.1080/ 21645698.2015.1129937

Aciksoz SB, Ozturk L, Gokmen OO, Römheld V, Cakmak I (2011) Effect of nitrogen on root release of phytosiderophores and root uptake of Fe (III)-phytosiderophore in Fe-deficient wheat plants. Physiol Plant 142(3):287-296. https://doi.org/10.1111/j.1399-3054.2011.01460.x

Ali MW, Borrill P (2020) Applying genomic resources to accelerate wheat biofortification. Heredity 125:386-395. https://doi.org/10.1038/s41437-020-0326-8

Alloway BJ (2009) Soil factors associated with zinc deficiency in crops and humans. Environ Geochem Health 31:537548. https://doi.org/10.1007/s10653-009-9255-4

Alomari DZ, Eggert K, Von Wirén N, Polley A, Plieske J, Ganal MW, Liu F, Pillen K, Röder MS (2019) Wholegenome association mapping and genomic prediction for iron concentration in wheat grains. Int J Mol Sci 20:76. https://doi.org/10.3390/ijms20010076

Andersson MS, Saltzman A, Virk PS, Pfeiffer W (2017) Progress update: crop development of biofortified staple food crops under Harvestplus. Afr J Food Agric Nutr Dev 17(2):11905-11935. https://www.ajol.info/index. php/ajfand/article/download/155123/144739. Accessed 4 Feb 2022

Aung MS, Masuda H, Kobayashi T, Nakanishi H, Yamakawa T, Nishizawa NK (2013) Iron biofortification of Myanmar rice. Front Plant Sci 4:158. https://doi.org/10.3389/ fpls.2013.00158

Banakar R, Alvarez Fernandez A, Díaz-Benito P, Abadia J, Capell T, Christou P (2017) Phytosiderophores determine thresholds for iron and zinc accumulation in biofortified rice endosperm while inhibiting the accumulation of cadmium. J Exp Bot 68:4983-4995. https://doi.org/10. 1093/jxb/erx304

Barma N, Hossain A, Hakim M, Mottaleb K, Alam M, Reza M, Rohman M (2019) Progress and challenges of wheat production in the era of climate change: a Bangladesh perspective. In: Hasanuzzaman $\mathrm{M}$ et al (eds) Wheat production in changing environments: responses, adaptation and tolerance. Springer Singapore, Singapore, pp 615-679

Bashir K, Seki M, Nishizawa NK (2019) The transport of essential micronutrients in rice. Mol Breed 39:12. https:// doi.org/10.1007/s11032-019-1077-1

Beal T, Massiot E, Arsenault JE, Smith MR, Hijmans RJ (2017) Global trends in dietary micronutrient supplies and estimated prevalence of inadequate intakes. PLoS One 12:e0175554. https://doi.org/10.1371/journal.pone. 0175554

Beasley JT, Bonneau JP, Sánchez-Palacios JT, Moreno-Moyano LT, Callahan DL, Tako E, Glahn RP, Lombi E, Johnson AAT (2019) Metabolic engineering of bread wheat improves grain iron concentration and bioavailability. Plant Biotechnol J 17:1514-1526. https://doi.org/10. 1111/pbi.13074

Beasley JT, Johnson AAT, Kolba N, Bonneau JP, Glahn RP, Ozeri L, Koren O, Tako E (2020) Nicotianamine-chelated iron positively affects iron status, intestinal morphology and microbial populations in vivo (Gallus gallus). Sci Rep 5(2):574. https://doi.org/10.1093/cdn/nzab0 44_005

Berendsen RL, Pieterse CMJ, Bakker PA (2012) The rhizosphere microbiome and plant health. Trends Plant Sci 17:478-486. https://doi.org/10.1016/j.tplants.2012.04. 001

Bohn L, Meyer AS, Rasmussen SK (2008) Phytate: impact on environment and human nutrition. A challenge for molecular breeding. J Zhejiang Univ Sci B 9:165-191. https://doi.org/10.1631/jzus.B0710640

Boonyaves K, Wu T-Y, Gruissem W, Bhullar NK (2017) Enhanced grain iron levels in rice expressing an ironregulated metal transporter, nicotianamine synthase, and ferritin gene cassette. Front Plant Sci 8:130. https://doi. org/10.3389/fpls.2017.00130

Borg S, Brinch-Pedersen H, Tauris B, Madsen LH, Darbani B, Noeparvar S, Holm PB (2012) Wheat ferritins: improving the iron content of the wheat grain. J Cereal Sci 56:204-213. https://doi.org/10.1016/j.jcs.2012.03.005

Bouis HE, Welch RM (2010) Biofortification - a sustainable agricultural strategy for reducing micronutrient malnutrition in the global south. Crop Sci 50:S-20-S-32. https:// doi.org/10.2135/cropsci2009.09.0531

Bouis H, Birol E, Boy E et al (2020) Food biofortification: reaping the benefits of science to overcome hidden hunger, no. 69. Presented at the October webinar on The Need for Agricultural Innovation to Sustainably Feed the World by 2050, online: Council for Agricultural Science and Technology (CAST)

Cakmak I (2008) Enrichment of cereal grains with zinc: agronomic or genetic biofortification? Plant Soil 302:1-17. https://doi.org/10.1007/s11104-007-9466-3

Cakmak I, Kutman UB (2018) Agronomic biofortification of cereals with zinc: a review. Soil Sci 69:172-180. https:// doi.org/10.1111/ejss.12437

Cakmak I, Pfeiffer WH, McClafferty B (2010a) Review: biofortification of durum wheat with zinc and iron. Cereal Chem 87:10-20. https://doi.org/10.1094/ CCHEM-87-1-0010 
Cakmak I, Kalayci M, Kaya Y et al (2010b) Biofortification and localization of zinc in wheat grain. J Agric Food Chem 58(16):9092-9102. https://doi.org/10.1021/jf101 $197 \mathrm{~h}$

Cakmak I, Pfeiffer WH, McClafferty B (2010c) Biofortification of durum wheat with zinc and iron. Cereal Chem 87:1020. https://doi.org/10.1094/CCHEM-87-1-0010

Carlson D, Nørgaard JV, Torun B, Cakmak I, Poulsen HD (2012) Bioavailability of trace elements in beans and zinc-biofortified wheat in pigs. Biol Trace Elem Res 150(1-3):147-153. https://doi.org/10.1007/ s12011-012-9453-2

Carvalho SMP, Vasconcelos MW (2013) Producing more with less: strategies and novel technologies for plant-based food biofortification. Food Res Int 54:961-971. https:// doi.org/10.1016/j.foodres.2012.12.021

Chandra AK, Kumar A, Bharati A, Joshi R, Agrawal A, Kumar S (2020) Microbial-assisted and genomic-assisted breeding: a two-way approach for the improvement of nutritional quality traits in agricultural crops. Biotech 10(1):2. https://doi.org/10.1007/s13205-019-1994-z

Chauhan BS, Mahajan G, Sardana V, Timsina J, Jat ML (2012) Chapter six - productivity and sustainability of the Ricewheat cropping system in the indo-Gangetic Plains of the Indian subcontinent: problems, opportunities, and strategies. In: Sparks DL (ed) Advances in agronomy. Academic Press, Elsevier, pp 315-369

Che P, Zhao ZY, Glassman K, Dolde D, Hu TX, Jones TJ, Gruis DF, Obukosia S, Wambugu F, Albertsen MC (2016) Elevated vitamin E content improves all-trans $\beta$-carotene accumulation and stability in biofortified sorghum. PNAS 113(39):11040-11045. https://doi.org/10. 1073/pnas.1605689113

Choi EY, Graham RM, Stangoulis JRC (2007) Semiquantitative analysis for selecting $\mathrm{Fe}$ - and $\mathrm{Zn}$-dense genotypes of staple food crops. J Food Compos Anal 20:496-505. https://doi.org/10.1016/j.jfca.2007.01.004

Clemens S (2019) Metal ligands in micronutrient acquisition and homeostasis. Plant Cell Environ 42:2902-2912. https://doi.org/10.1111/pce.13627

Coccina A, Cavaganro TR, Pellegrino E, Ercoli L, McLaughlin M, Watts-Williams SJ (2019) The mycorrhizal pathway of zinc uptake contributes to zinc accumulation in barley and wheat grain. BMC Plant Biol 19(1):133. https://doi.org/10.1186/s12870-019-1741-y

Colle C, Madoz-Escande C, Leclerc E (2009) Foliar transfer into the biosphere: review of translocation factors to cereal grains. J Environ Radioact 100:683-689. https:// doi.org/10.1016/j.jenvrad.2008.10.002

Connorton JM, Jones ER, Rodríguez-Ramiro I, FairweatherTait S, Uauy C, Balk J (2017) Wheat vacuolar iron transporter tavit2 transports $\mathrm{Fe}$ and $\mathrm{Mn}$ and is effective for biofortification. Plant Physiol 174:2434-2444. https://doi.org/10.1104/pp.17.00672

Das S, Chaki AKC, Hossain A (2019) Breeding and agronomic approaches for the biofortification of zinc in wheat (Triticum aestivum L.) to combat zinc deficiency in millions of a population: a Bangladesh perspective. Acta Agrobot 7(2):1770. https://doi.org/10.5586/aa. 1770
Dharejo K, Rahim AA, Yusop MK, Wahid SA, Junejo N (2011) Spatial variability of cu, $\mathrm{Mn}$ and $\mathrm{Zn}$ in marginal sandy beach ridges soil. Afr J Agric Res 15:3493-3498

Duxbury JM BM, Johnson SE, Lauren JG, Meisner CA, Welch RM (2006) Opportunities and constraints for addressing human mineral micronutrient malnutrition through soil management. $18^{\text {th }}$ World Congress of Soil Science, Philadelphia, USA

Ercoli L, Schubler A, Arduini I, Pellegrino E (2017) Strong increase of durum wheat iron and zinc content by fieldinoculation with arbuscular mycorrhizal fungi at different soil nitrogen availabilities. Plant Soil 419:153-167. https://doi.org/10.1007/s11104-017-3319-5

Farooq M, Wahid A, Siddique KHM (2012) Micronutrient application through seed treatments: a review. J Soil Sci Plant Nutr 12:125-142. https://doi.org/10.4067/S071895162012000100011

Gabriel J, Alonso-Ayuso M, García González I, Hontoria Fernández C, Quemada M (2016) Nitrogen use efficiency and fertiliser fate in a long-term experiment with winter cover crops. Eur J Agron 79:14-22. https://doi.org/10. 1016/j.eja.2016.04.015

Gan Y, Hamel C, O'Donovan J, Cutforth H, Zentner R, Campbell C, Niu Y, Poppy L (2015) Diversifying crop rotations with pulses enhances system productivity. Sci Rep 5:14625. https://doi.org/10.1038/srep14625

Garcia-Oliveira AL, Chander S, Ortiz R, Menkir A, Gedil M (2018) Genetic basis and breeding perspectives of grain iron and zinc enrichment in cereals. Front Plant Sci 9. https://doi.org/10.3389/fpls.2018.00937

Garnett TP, Graham RD (2005) Distribution and remobilization of iron and copper in wheat. Ann Bot 95(5):817826. https://doi.org/10.1093/aob/mci085

Gibson RS (2006) Zinc: the missing link in combating micronutrient malnutrition in developing countries. PNS 65:51-60. https://doi.org/10.1079/pns2005474

Glahn RP, Wiesinger JA, Lungaho MG (2020) Iron concentrations in biofortified beans and nonbiofortified marketplace varieties in East Africa are similar. J Nutr 150:3013-3023. https://doi.org/10.1093/jn/nxaa193

Graham RD, Ascher JS, Hynes SC (1992) Selecting zinc-efficient cereal genotypes for soils of low zinc status. Plant Soil 146(1):241-250. https://doi.org/10.1007/BF000 12018

Graham RD, Senadhira D, Ortiz-Monasterio I (1997) A strategy for breeding staple-food crops with high micronutrient density. Soil Sci Plant Nutr 43:1153-1157. https:// doi.org/10.1080/00380768.1997.11863734

Graham RD, Welch RM, Saunders DA, Ortiz-Monasterio I, Bouis HE, Bonierbale M, De Haan S, Burgos G, Thiele G, Liria R, Meisner CA (2007) Nutritious subsistence food systems. Adv Agron 1(92):1-74. https://doi.org/10. 1016/S0065-2113(04)92001-9

Grusak MA (1995) Whole-root iron (III)-reductase activity throughout the life cycle of iron-grown Pisum sativum L (Fabaceae)-relevance to the iron nutrition of developing seeds. Planta 197(1):111-117. https://www.jstor.org/stable/23384206. Accessed 4 Feb 2022

Guild GE, Stangoulis JCR (2021) EDXRF for screening micronutrients in lentil and sorghum biofortification breeding 
programs. Plant Soil 463:461-469. https://doi.org/10. 1007/s11104-021-04922-z

Guild GE, Paltridge NG, Andersson MS, Stangoulis JCR (2017) An energy-dispersive X-ray fluorescence method for analysing $\mathrm{Fe}$ and $\mathrm{Zn}$ in common bean, maize and cowpea biofortification programs. Plant Soil 419:457466. https://doi.org/10.1007/s11104-017-3352-4

Hakim S, Naqqash T, Nawaz MS, Laraib I, Siddique MJ, Zia R, Mirza MS, Imran A (2021) Rhizosphere engineering with plant growth-promoting microorganisms for agriculture and ecological sustainability. Front Sustain Food Syst 5. https://doi.org/10.3389/fsufs.2021.617157

Hegelund JN, Schiller M, Kichey T, Hansen TH, Pedas P, Husted S, Schjoerring JK (2012) Barley Metallothioneins: MT3 and MT4 are localized in the grain aleurone layer and show differential zinc binding. Plant Physiol 159:1125-1137. https://doi.org/10.1104/pp.112.197798

Hobbs PR, Sayre K, Gupta R (2008) The role of conservation agriculture in sustainable agriculture. Philos Trans R Soc Lond Ser B Biol Sci 363:543-555. https://doi.org/10. 1098/rstb.2007.2169

Hocking PJ (1994) Dry-matter production, mineral nutrient concentrations, and nutrient distribution and redistribution in irrigated spring wheat. J Plant Nutr 17(8):12891308. https://doi.org/10.1080/01904169409364807

Hoppler M, Schönbächler A, Meile L, Hurrell RF, Walczyk $\mathrm{T}$ (2008) Ferritin-Iron is released during boiling and in vitro gastric digestion. J Nutr 138:878-884. https://doi. org/10.1093/jn/138.5.878

Hurrell R, Egli I (2010) Iron bioavailability and dietary reference values. Am J Clin Nutr 91:1461s-1467s. https://doi. org/10.3945/ajcn.2010.28674F

Hussain S, Maqsood MA, Rengel Z, Aziz TJ (2012) Biofortification and estimated human bioavailability of zinc in wheat grains as influenced by methods of zinc application. Plant Soil 361:279-290. https://doi.org/10.1007/ s11104-012-1217-4

Impa SM, Morete MJ, Ismail AM, Schulin M, Johson-Beebout SE (2013) Zn uptake, translocation, and grain $\mathrm{Zn}$ loading in rice (Oryza sativa L.) genotypes selected for $\mathrm{Zn}$ deficiency tolerance and high grain Zn. J Exp Bot 64(10). https://doi.org/10.1093/jxb/ert118

Ishimaru Y, Suzuki M, Tsukamoto T, Suzuki K, Nakazono M, Kobayashi T, Wada Y, Watanabe S, Matsuhashi S, Takahashi M, Nakanishi H, Mori S, Nishizawa NK (2006) Rice plants take up iron as an Fe3+-phytosiderophore and as Fe2+. Plant J 45:335-346. https://doi. org/10.1111/j.1365-313X.2005.02624.x

Jaksomsak P, Tuiwong P, Rerkasem B, Guilf G, Palmer L, Stangoulis JCR (2018) The impact of foliar applied zinc fertilizer on zinc and phytate accumulation in dorsal and ventral grain sections of four Thai rice varieties with different grain zinc. J Cereal Sci 79:6-12. https:// doi.org/10.1016/j.jcs.2017.09.004

Jiang W, Struik PC, Lingna J, Van Keulen H, Ming Z, Stomph TJ (2007) Uptake and distribution of rootapplied or foliar-applied $65 \mathrm{Zn}$ after flowering in aerobic rice. Ann Appl Biol 150:383-391. https://doi.org/ 10.1111/j.1744-7348.2007.00138.x

Johnson AA, Kyriacou B, Callahan DL et al (2011) Constitutive overexpression of the OsNAS gene family reveals single-gene strategies for effective iron- and zinc-biofortification of rice endosperm. PLoS One 6(9):e24476. https://doi.org/10.1371/journal.pone.0024476

Khoshgoftarmanesh AH, Schulin R, Chaney RL, Daneshbakhsh B, Afyuni MJ (2010) Micronutrient-efficient genotypes for crop yield and nutritional quality in sustainable agriculture. A review. Agron Sustain Dev 30:83-107. https://doi.org/10.1051/agro/2009017

Kiran A, Wakeel A, Sultana R, Khalid A, Qurrat-ul-Ain MR, Shahzad AN, Khan S, Noor M (2021) Concentration and localization of $\mathrm{Fe}$ and $\mathrm{Zn}$ in wheat grain as affected by its application to soil and foliage. Bull Environ Contam Toxicol 106(5):852-858. https://doi.org/10.1007/ s00128-021-03183-x

Knez M, Tako E, Glahn RP, Kolba N, de Courcy-Ireland E, Stangoulis JCR (2018) Linoleic acid:dihomo- $\gamma$ linolenic acid ratio predicts the efficacy of Zn-biofortified wheat in chicken (Gallus gallus). J Agr Food Chem 66:1394-1400. https://doi.org/10.1021/acs.jafc.7b049 05

Kobayashi T, Ogo Y, Aung MS, Nozoye T, Itai RN, Nakanishi H, Yamakawa T, Nishizawa NK (2010) The spatial expression and regulation of transcription factors IDEF1 and IDEF2. Ann Bot 105:1109-1117. https:// doi.org/10.1093/aob/mcq002

Kosová K, Vítámvás P, Prášil IT (2014) Wheat and barley dehydrins under cold, drought, and salinity - what can LEA-II proteins tell us about plant stress response? Front Plant Sci 5:343-343. https://doi.org/10.3389/fpls.2014. 00343

Ku YS, Rehman HM, Lam HM (2019) Possible roles of rhizospheric and endophytic microbes to provide a safe and affordable means of crop biofortification. Agronomy 9:764. https://doi.org/10.3390/agronomy9110764

Kubota H, Iqbal M, Quideau S, Dyck M, Spaner D (2018) Agronomic and physiological aspects of nitrogen use efficiency in conventional and organic cereal-based production systems. Renew Agr Food Syst 33:443-466. https://doi.org/10.1017/s1742170517000163

Kutman UB, Yildiz B, Cakmak I (2011) Improved nitrogen status enhances zinc and iron concentrations both in the whole grain and the endosperm fraction of wheat. $\mathbf{J}$ Cereal Sci 53:118-125. https://doi.org/10.1016/J.JCS. 2010.10.006

Kyriacou B, Moore KL, Paterson D, De Jonge MD, Howard DL, Stangoulis JCR, Tester M, Lombi E, Johnson AAT (2014) Localization of iron in rice grain using synchrotron X-ray fluorescence microscopy and high-resolution secondary ion mass spectrometry. J Cereal Sci 59:173180. https://doi.org/10.1016/j.jcs.2013.12.006

Lehmann A, Veresoglou SD, Leifheit EF, Rillig MC (2014) Arbuscular mycorrhizal influence on zinc nutrition in crop plants - a meta-analysis. Soil Biol Biochem 69:123131. https://doi.org/10.1016/j.soilbio.2013.11.001

Li D, Xu X, Hu X, Liu Q, Wang Z, Zhang H, Wang H, Wei M, Wang H, Liu H, Li C (2015) Genome-wide analysis and heavy metal-induced expression profialikng of the hma gene family in populus trichocarpa. Front Plant Sci 6:1149. https://doi.org/10.3389/fpls.2015.01149

Liu A, Gao F, Kanno Y, Jordan MC, Kamiya Y, Seo M, Ayele BT (2013) Regulation of wheat seed dormancy 
by after-ripening is mediated by specific transcriptional switches that induce changes in seed hormone metabolism and signaling. PLoS One 8(2):e56570. https://doi. org/10.1371/journal.pone.0056570

Lobell DB, Gourdji SM (2012) The influence of climate change on global crop productivity. Plant Physiol 160:16861697. https://doi.org/10.1104/pp.112.208298

Lobell DB, Sibley A, Ivan Ortiz-monasterio J (2012) Extreme heat effects on wheat senescence in India. Nat Clim Chang 2:186-189. http://www.nature.com/doifinder/10. 1038/nclimate1356. Accessed 4 Feb 2022

Lung'aho MG, Mwaniki AM, Szalma SJ, Hart JJ, Rutzke MA, Kochian LV, Glahn RP, Hoekenga OA (2011) Genetic and physiological analysis of iron biofortification in maize kernels. PLoS One 6:e20429. https://doi.org/10. 1371/journal.pone.0020429

Ma BL, Zheng ZM (2018) Nutrient uptake of iron, zinc, magnesium, and copper in transgenic maize (Zea mays) as affected by rotation systems and $\mathrm{N}$ application rates. Nutr Cycl Agroecosyst 112:27-43. https://doi.org/10.1007/ s10705-018-9925-7

Mady Kaye N, Mason SC, Jackson DS, Galusha TD (2007) Crop rotation and soil amendment alters sorghum grain qualityFood. Sci Technol 47:722-727. https://doi.org/10. 2135/cropsci2006.05.0346

Manyevere A, Muchaonyerwa P, Mnkeni PNS, Dhau I (2017) Spatial variability of selected soil micronutrients under smallholder crop production in Zanyokwe, eastern cape, South Africa. South Afr J Plant Soil 34:339-349. https:// doi.org/10.1080/02571862.2016.1266399

Marr KM, Batten GD, Blakeney AB (1995) Relationships between minerals in Australian brown rice. J Sci Food Agric 68(3):285-291. https://doi.org/10.1002/jsfa.27406 80305

Marschner P (2012) Rhizosphere biology, chapter 15. In: Marschner's mineral nutrition of higher plants, 3rd edn. Academic Press, Lonon, pp 369-388. https://doi.org/ 10.1016/B978-0-12-384905-2.00015-7

Masuda H, Ishimaru Y, Aung MS, Kobayashi T, Kakei Y, Takahashi M, Higuchi K, Nakanishi H, Nishizawa NK (2012) Iron biofortification in rice by the introduction of multiple genes involved in iron nutrition. Sci Report 2:543. https://doi.org/10.1038/srep00543

Masuda H, Kobayashi T, Ishimaru Y, Takahashi M, Aung M, Nakanishi H, Mori S, Nishizawa N (2013) Iron-biofortification in rice by the introduction of three barley genes participated in mugineic acid biosynthesis with soybean ferritin gene. Front Plant Sci 4:132. https:// doi.org/10.3389/fpls.2013.00132

Morais-Dias D, Kolba N, Binyamin D, Ziv O, Regini Nutti M, Duarte Martino HS, Glahn RP, Koren O, Tako E (2018) Iron biofortified carioca bean (phaseolus vulgaris 1.)- based Brazilian diet delivers more absorbable iron and affects the gut microbiota in vivo (Gallus gallus). Nutrients 10(12):1970. https://doi.org/10.3390/ nu10121970

Mori S (1999) Iron acquisition by plants. Curr Opin Plant Biol 2:250-253. https://doi.org/10.1016/s13695266(99)80043-0

Murphy KM, Reeves PG, Jones SS (2008) Relationship between yield and mineral nutrient concentrations in historical and modern spring wheat cultivars. Euphytica 163:381-390. https://doi.org/10. 1007/s10681-008-9681-x

Myers SS, Zanobetti A, Kloog I, Huybers P, Leakey ADB, Bloom AJ, Carlisle E, Dietterich LH, Fitzgerald G, Hasegawa T, Holbrook NM, Nelson RL, Ottman MJ, Raboy V, Sakai H, Sartor KA, Schwartz J, Seneweera S, Tausz M, Usui Y (2014) Increasing CO2 threatens human nutrition. Nature 510:139-142. https://doi.org/10. 1038/nature13179

Nguyen TT, Marschner P (2017) Soil respiration, microbial biomass and nutrient availability in soil after addition of residues with adjusted $\mathrm{N}$ and $\mathrm{P}$ concentrations. Pedosphere 27(1):76-85. https://doi.org/10.1016/S10020160(17)60297-2

Nishiyama R, Kato M, Nagata S, Yanagisawa S, Yoneyama $\mathrm{T}$ (2012) Identification of zn-nicotianamine and fe-2'deoxymugineic acid in the phloem sap from rice plants (oryza sativa 1.). Plant Cell Physiol 53:381-390. https:// doi.org/10.1093/pcp/pcr188

Nishiyama R, Tanoi K, Yanagisawa S, Yoneyama T (2013) Quantification of zinc transport via the phloem to the grain in rice plants (Oryza sativa L.) at early grain-filling by a combination of mathematical modeling and $65 \mathrm{Zn}$ tracing. Soil Sci Plant Nutr 59:750-755

Ozturk L, Yazici MA, Yucel C, Torun A, Cekic C, Bagci A, Ozkan H, Braun HJ, Sayers Z, Cakmak I (2006) Concentration and localization of zinc during seed development and germination in wheat. Physiol Plant 128:144-152

Palmer CM, Guerinot ML (2009) Facing the challenges of $\mathrm{cu}, \mathrm{Fe}$ and $\mathrm{Zn}$ homeostasis in plants. Nat Chem Biol 5(5):333-340. https://doi.org/10.1038/nchembio.166

Palmer LJ, Palmer LT, Rutzke MA, Graham RD, Stangoulis JCR (2014) Nutrient variability in phloem: examining changes in $\mathrm{K}, \mathrm{mg}, \mathrm{Zn}$ and $\mathrm{Fe}$ concentration during grain loading in common wheat (Triticum aestivum). Physiol Plant 152:729-737. https://doi.org/10.1111/ppl.12211

Palmgren MG, Clemens S, Williams LE, Krämer U, Borg S, Schjørring JK, Sanders D (2008) Zinc biofortification of cereals: problems and solutions. Trends Plant Sci 13:464-473

Paltridge NG, Milham PJ, Ortiz-Monasterio JI, Velu G, Yasmin Z, Palmer LJ, Guild GE, Stangoulis JC (2012a) Energy-dispersive X-ray fluorescence spectrometry as a tool for zinc, iron and selenium analysis in whole grain wheat. Plant Soil 361:261-269. https://doi.org/10.1007/ s11104-012-1423-0

Paltridge NG, Palmer LJ, Milham PJ, Guild GE, Stangoulis JCR (2012b) Energy-dispersive X-ray fluorescence analysis of zinc and iron concentration in rice and pearl millet grain. Plant Soil 361:251-260. https://doi.org/10. 1007/s11104-011-1104-4

Paul S, Ali N, Datta SK, Datta K (2014) Development of an iron-enriched high-yieldings indica rice cultivar by introgression of a high-iron trait from transgenic iron-biofortified rice. Plant Foods Hum Nutr 69:203-208. https://doi. org/10.1007/s11130-014-0431-z

Pearson JN, Rengel Z, Jenner CF, Graham RD (1996) Manipulation of xylem transport affects $\mathrm{Zn}$ and Mn transport into developing wheat grains of cultured ears. Physiol 
Plant 98:229-234. https://doi.org/10.1034/j.1399-3054. 1996.980202.x

Peck AW, McDonald GK, Graham RD (2008) Zinc nutrition influences the protein composition of flour in bread wheat (Triticum aestivum L.). J Cereal Sci 47:266-274. https://doi.org/10.1016/j.jcs.2007.04.006

Plenchette C, Clermont-Dauphin C, Meynard JM, Fortin JA (2005) Managing arbuscular mycorrhizal fungi in cropping systems. Can J Plant Sci 85:31-40. https://doi.org/ 10.4141/p03-159

Poblaciones MJ, Rengel Z (2016) Soil and foliar zinc biofortification in field pea (Pisum sativum L.): grain accumulation and bioavailability in raw and cooked grains. Food Chem 212:427-433. https://doi.org/10.1016/j.foodchem. 2016.05.189

Prasad R, Shivay YS, Kumar DJ (2014) Agronomic biofortification of cereal grains with iron and zinc. Adv Agron 125:55-91. https://doi.org/10.1016/B978-0-12-800137$0.00002-9$

Prom-U-Thai C, Rashid A, Ram H, Zou C, Guilherme L, Corguinhan A, Guo S, Kaur C, Naeem A, Yamuangmorn S, Ashraf MY, Sohu VS, Zhang Y, Martins F, Jumrus S, Tutus Y, Yazici MA, Cakmak I (2020) Simultaneous biofortification of rice with zinc, iodine, iron and selenium through foliar treatment of a micronutrient cocktail in five countries. Front Plant Sci 11:589835. https://doi.org/ 10.3389/fpls.2020.589835

Puig S, Peñarrubia L (2009) Placing metal micronutrients in context: transport and distribution in plants. Curr Opin Plant Biol 12:299-306. https://doi.org/10.1016/j.pbi. 2009.04.008

Qu LQ, Yoshihara T, Ooyama A, Goto F, Takaiwa F (2005) Iron accumulation does not parallel the high expression level of ferritin in transgenic rice seeds. Planta 222:225233. https://doi.org/10.1007/s00425-005-1530-8

Ramzan S, Bhat MA, Kirmani N, Rasool R (2014) Fractionation of zinc and their association with soil properties in soils of Kashmir Himalayas. Int Inv J Agric Soil Sci 2(8):132-142

Raney T, Croppenstedt A, Garrett J, Lowder S (2013) The state of food and agriculture 2013: food Systems for Better Nutrition. Food and Agriculture Organization of the United Nations. ISBN: 978-92-5-107671-2

Reed S, Neuman H, Glahn RP, Koren O, Tako E (2017) Characterizing the gut (Gallus gallus) microbiota following the consumption of an iron biofortified Rwandan cream seeded carioca (Phaseolus Vulgaris L.) bean-based diet. PLoS One 12(8):e0182431. https://doi.org/10.1371/journ al.pone.0182431

Reed S, Knez M, Uzan A, Stangoulis JCR, Glahn RP, Koren O, Tako E (2018) Alterations in the gut (gallus gallus) microbiota following the consumption of zinc biofortified wheat (triticum aestivum)-based diet. J Agric Food Chem 66:6291-6299. https://doi.org/10.1021/acs.jafc. $8 \mathrm{~b} 01481$

Rengel Z, Batten G, Crowley DE (1999) Agronomic approaches for improving the micronutrient density in edible portions of field crops. Filed Crop Res 60:27-40

Reza SK, Nayak DC, Mukhopadhyay S, Chattopadhyay T, Singh SK (2017) Characterizing spatial variability of soil properties in alluvial soils of India using geostatistics and geographical information system. Arch Agron Soil Sci 63:1489-1498. https://doi.org/10.1080/03650340.2017. 1296134

Ricachenevsky F, Menguer P, Sperotto R, Williams L, Fett J (2013) Roles of plant metal tolerance proteins (MTP) in metal storage and potential use in biofortification strategies. Front Plant Sci 4:144. https://doi.org/10.3389/fpls. 2013.00144

Ricroch AE, Hénard-Damave MC (2016) Next biotech plants: new traits, crops, developers and technologies for addressing global challenges. Crit Rev Biotechnol 36:675-690. https://doi.org/10.3109/07388551.2015. 1004521

Riedell WE, Osborne SL (2017) Row and forage crop rotation effects on maize mineral nutrition and yield. Can J Plant Sci 97:645-653. https://doi.org/10.1139/cjps-2017-0006

Riedell WE, Pikul JL, Jaradat AA, Schumacher TE (2009) Crop rotation and nitrogen input effects on soil fertility, maize mineral nutrition, yield, and seed composition. J Agron 101(4):870-879. https://doi.org/10.2134/agron j2008.0186x

Rodrigues ML, Nakayasu ES, Oliveira DL, Nimrichter L, Nosanchuk JD, Almeida IC, Casadevall A (2008) Extracellular vesicles produced by Cryptococcus neoformans contain protein components associated with virulence. Eukaryot Cell 7:58-67. https://doi.org/10.1128/EC. 00370-07

Rosa M, Prado C, Podazza G, Interdonato R, González JA, Hilal M, Prado FE (2009) Soluble sugars. Plant Signal Behav 4(5):388-393. https://doi.org/10.4161/psb.4.5. 8294

Rosado JL, Hambidge KM, Miller LV et al (2009) The quantity of zinc absorbed from wheat in adult women is enhanced by biofortification. J Nutr 139(10):1920-1925. https:// doi.org/10.3945/jn.109.107755

Saalbach I, Mora-ramírez I, Weichert N, Andersch F, Guild G, Wieser H, Koehler P, Stangoulis J, Kumlehn J, Weschke $\mathrm{W}$, Weber H (2014) Increased grain yield and micronutrient concentration in transgenic winter wheat by ectopic expression of a barley sucrose transporter. J Cereal Sci 60:75-81. https://doi.org/10.1016/j.jcs.2014.01.017

Saha S, Chakraborty M, Padhan D, Saha B, Murmu S, Batabyal K, Seth A, Hazra GC, Mandal B, Bell RW (2017) Agronomic biofortification of zinc in rice: influence of cultivars and zinc application methods on grain yield and zinc bioavailability. Field Crop Res 210:52-60. https:// doi.org/10.1016/j.fcr.2017.05.023

Sharma SK, Johri BN, Ramesh A, Joshi OP, Sai Prasad SV (2011) Selection of plant growth-promoting Pseudomonas spp. that enhanced productivity of soybeanwheat cropping system in Central India. J Microbiol Biotechnol 21:1127-1142. https://doi.org/10.4014/jmb.1012. 12018

Shivay YS, Prasad R (2012) Zinc-coated urea improves productivity and quality of basmati rice (oryza sativa 1.) under zinc stress condition. Plant Nutr 35:928-951. https://doi. org/10.1080/01904167.2012.663444

Shukla AK, Sinha NK, Tiwari PK, Prakash C, Behera SK, Lenka NK, Singh VK, Dwivedi BS, Majumdar K, Kumar A, Srivastava PC, Pachauri SP, Meena MC, Lakaria BL, Siddiqui S (2017) Spatial distribution and management 
zones for Sulphur and micronutrients in Shivalik Himalayan region of India. Land Degrad Dev 28:959-969. https://doi.org/10.1002/ldr.2673

Singh B, Natesan SKA, Singh BK, Usha K (2005) Improving zinc efficiency of cereals under zinc deficiency. Curr Sci 88:36-44. https://www.jstor.org/stable/24110091. Accessed 4 Feb 2022

Singh SP, Keller B, Gruissem W, Bhullar NK (2017) Rice nicotianamine synthase 2 expression improves dietary iron and zinc levels in wheat. Theor Appl Genet 130:283292. https://doi.org/10.1007/s00122-016-2808-x

Sosa P, Guild G, Burgos G, Bonierbale M, Zum Felde T (2018) Potential and application of X-ray fluorescence spectrometry to estimate iron and zinc concentration in potato tubers. J Food Compos Anal 70:22-27. https://doi.org/ 10.1016/j.jfca.2018.03.004

St. Luce M, Grant CA, Ziadi N, Zebarth BJ, O'Donovan JT, Blackshaw RE, Harker KN, Johnson EN, Gan Y, Lafond GP, May WE, Malhi SS, Turkington TK, Lupwayi NZ, McLaren DL (2016) Preceding crops and nitrogen fertilization influence soil nitrogen cycling in no-till canola and wheat cropping systems. Field Crop Res 191:20-32. https://doi.org/10.1016/j.fcr.2016.02.014

Stangoulis J, Sison C (2008) Crop sampling protocols for micronutrient analysis. Harvest Plus Tech Monograph 7:20

Stomph TJ, Choi EY, Stangoulis JCR (2011) Temporal dynamics in wheat grain zinc distribution: is sink limitation the key? Ann Bot 107:927-937. https://doi.org/10.1093/aob/ mcr040

Suzuki M, Bashir K, Inoue H, Takahashi M, Nakanishi H, Nishizawa NK (2012) Accumulation of starch in Zndeficient rice. Rice 5:1:9. https://doi.org/10.1186/ 1939-8433-5-9

Szymańska S, Płociniczak T, Piotrowska-Seget Z, Złoch M, Ruppel S, Hrynkiewicz K (2016) Metabolic potential and community structure of endophytic and rhizosphere bacteria associated with the roots of the halophyte Aster tripolium L. Microbiol Res 182:68-79. https://doi.org/ 10.1016/j.micres.2015.09.007.kneyž

Thorne JH (1985) Phloem unloading of C and N assimilates in developing seeds. Annu Rev Plant Biol 36:317-343. https://doi.org/10.1146/annurev.pp.36.060185.001533

Tong JY, Sun MJ, Wang Y, Zhang Y, Rasheed A, Li M, Xia XC, He ZH, Hao YF (2020) Dissection of molecular processes and genetic architecture underlying iron and zinc homeostasis for biofortification: from model plants to common wheat. Int J Mol Sci 21(23):9280. https://doi. org/10.3390/ijms21239280

Tonitto C, David MB, Drinkwater LE (2006) Replacing bare fallows with cover crops in fertilizer-intensive cropping systems: a meta-analysis of crop yield and $\mathrm{N}$ dynamics. Agric Ecosyst Environ 112(1):58-72 https://agris.fao. org/agris-search/search.do?recordID=US201301053056

Trijatmiko KR, Dueñas C, Tsakirpaloglou N, Torrizo L, Arines FM et al (2016) Biofortified indica rice attains iron and zinc nutrition dietary targets in the field. Sci Rep 6:19792. https://doi.org/10.1038/srep19792

United Nations (2016) Sustainable Development Goal 2 - Zero Hunger. Available at: www.undp.org/content/undp/en/ home/sustainable-development-goals/goal-2-zero-hunger/targets. Accessed 4 Feb 2022

Vasconcelos MW, Gruissem W, Bhullar NK (2017) Iron biofortification in the 21 st century: setting realistic targets, overcoming obstacles, and new strategies for healthy nutrition. Curr Opin Biotechnol 44:8-15. https://doi.org/ 10.1016/j.copbio.2016.10.001

Velu G, Ortiz-Monasterio I, Cakmak I, Hao Y, Singh RJ (2014) Biofortification strategies to increase grain zinc and iron concentrations in wheat. J Cereal Sci 59:365-372

Velu G, Crossa J, Singh RP, Hao Y, Dreisigacker S, Perezrodriguez $\mathrm{P}$, Joshi AK, Chatrath R, Gupta V, Balasubramaniam A, Tiwari C, Mishra VK, Sohu VS, Mavi GS (2016) Genomic prediction for grain zinc and iron concentrations in spring wheat. Theorl Appl Genet 129:1595-1605. https://doi.org/10.1016/j.jcs.2013.09. 001

Velu G, Crespo Herrera L, Guzman C, Huerta J, Payne T, Singh RP (2018a) Assessing genetic diversity to breed competitive biofortified wheat with enhanced grain $\mathrm{Zn}$ and Fe concentrations. Front Plant Sci 9:1971. https:// doi.org/10.3389/fpls.2018.01971

Velu G, Singh RP, Crespo-herrera L, Juliana P, Dreisigacker S, Valluru R, Stangoulis JCR, Sohu VS, Mavi GS, Mishra VK, Balasubramaniam A, Chatrath R, Gupta V, Singh GP, Joshi AK (2018b) Genetic dissection of grain zinc concentration in spring wheat for mainstreaming biofortification in CIMMYT wheat breeding. Sci Rep 8:13526. https://doi.org/10.1038/s41598-018-31951-z

Venkatesh MS, Hazra KK, Ghosh PK, Khuswah BL, Ganeshamurthy AN, Ali M, Singh J, Mathur RS (2017) Longterm effect of crop rotation and nutrient management on soil-plant nutrient cycling and nutrient budgeting in indo-Gangetic plains of India. Arch Agron Soil Sci 63:2007-2022. https://doi.org/10.1080/03650340.2017. 1320392

Wang Y, Cheng X, Shan Q, Zhang Y, Liu J, Gao C, Qiu J-L (2014) Simultaneous editing of three homoeoalleles in hexaploid bread wheat confers heritable resistance to powdery mildew. Nat Biotech 32:947-951. https://doi. org/10.1038/nbt.2969

Wang DR, Agosto-pérez FJ, Chebotarov D, Shi Y, Marchini J, Fitzgerald M, Mcnally KL, Alexandrov N, Mccouch SR (2018) An imputation platform to enhance integration of rice genetic resources. Nature Comm 9:3519. https://doi. org/10.1038/s41467-018-05538-1

Waters BM, Uauy C, Dubcovsky J, Grusak MA (2009) Wheat (Triticum aestivum) NAM proteins regulate the translocation of iron, zinc, and nitrogen compounds from vegetative tissues to grain. J Exp Bot 60:4263-4274. https:// doi.org/10.1093/jxb/erp257

Wei Y, Shohag MJ, Yang X (2012) Biofortification and bioavailability of rice grain zinc as affected by different forms of foliar zinc fertilization. PLoS One 7:e45428. https:// doi.org/10.1371/journal.pone.0045428

Welch RM, Graham RD (2004) Breeding for micronutrients in staple food crops from a human nutrition perspective. $\mathrm{J}$ Exp Bot 55:353-364. https://doi.org/10.1093/jxb/erh064

Welch RM, Graham RD (2005) Agriculture: the real nexus for enhancing bioavailable micronutrients in food crops. 
J Trace Elem Med Biol 18:299-307. https://doi.org/10. 1016/j.jtemb.2005.03.001

Welch RM, House WA, Ortiz-Monasterio I, Cheng Z (2005) Potential for improving bioavailable zinc in wheat grain (Triticum species) through plant breeding. J Agric Food Chem 53:2176-2180. https://doi.org/10.1021/jf040238x

White PJ, Broadley MR (2011) Physiological limits to zinc biofortification of edible crops. Front Plant Sci 17(2):80. https://doi.org/10.3389/fpls.2011.00080

Wissuwa M, Ismail AM, Graham RJP (2008) Rice grain zinc concentrations as affected by genotype, native soil-zinc availability, and zinc fertilization. Plant Soil 306:37-48. https://doi.org/10.1007/s11104-007-9368-4

World Health Organization (2021) The state of food security and nutrition in the world 2018: building climate resilience for food security and nutrition. http://www.fao. org/3/i9553en/i9553en.pdf. Accessed 4 Feb 2022

Wu XL, Hu ZL (2021) Meta-analysis of QTL mapping experiments (2012) Meta-analysis of QTL mapping experiments. In: Rifkin SA (ed) Quantitative trait loci: methods and protocols. Humana Press, Totowa, pp 145-171

Xu G, Zhang J, Lam HM, Wang Z, Yang J (2007) Hormonal changes are related to the poor grain filling in the inferior spikelets of rice cultivated under non-flooded and mulched condition. Field Crop Res 10(11):53-61. https:// doi.org/10.1016/J.FCR.2006.09.008

Yang XW, Tian XH, Gale WJ, Cao YX, Lu XC, Zhao AQ (2011) Effect of soil and foliar zinc application on zinc concentration and bioavailability in wheat grain grown on potentially zinc-deficient soil. Cereal Res Commun 39:535-543. https://www.jstor.org/stable/23792319. Accessed 4 Feb 2022

Yazici MA, Asif M, Tutus Y et al (2021) Reduced root mycorrhizal colonization as affected by phosphorus fertilization is responsible for high cadmium accumulation in wheat. Plant Soil 468:19-35. https://doi.org/10.1007/ s11104-021-05041-5
Yoneyama T, Gosho T, Kato M, Goto S, Hayashi H (2010) Xylem and phloem transport of cd, $\mathrm{Zn}$ and $\mathrm{Fe}$ into the grains of rice plants (Oryza sativa L.) grown in continuously flooded cd-contaminated soil. Soil Sci Plant Nutr 56:445-453. https://doi.org/10.1111/j.1747-0765.2010. 00481.x

Yoo MS, James BR (2002) Zinc extractability as a function of $\mathrm{Ph}$ in organic waste-amended soils. Soil Sci 167(4):246-259. https://doi.org/10.1097/00010694200204000-00002

Zee S, O’brien T (1970) A special type of tracheary element associated with 'xylem discontinuity' in the floral axis of wheat. Austr J Biol Sci 23:783-792. https://doi.org/10. 1071/BI9700783

Zhang CD, Romheld V, Marschner H (1995) Retranslocation of iron from primary leaves of bean plants grown under iron deficiency. J Plant Physiol 146:268-272. https://doi.org/ 10.1016/S0176-1617(11)82052-3

Zhang WH, Zhou Y, Dibley KE, Tyerman SD, Furbank RT, Patrick JW (2007) Review: nutrient loading of developing seeds. Funct Plant Biol 34(4):314-331. https://doi. org/10.1071/FP06271

Zou C, Du Y, Rashid A et al (2019) Simultaneous biofortification of wheat with zinc, iodine, selenium, and iron through foliar treatment of a micronutrient cocktail in six countries. J Agric Food Chem 67(29):8096-8106. https://doi.org/10.1021/cs.j300afc.9b01829

Publisher's note Springer Nature remains neutral with regard to jurisdictional claims in published maps and institutional affiliations. 